\title{
Myofibroblasts in the Infarct Area: Concepts and Challenges
}

Citation for published version (APA):

Daskalopoulos, E. P., Janssen, B. J. A., \& Blankesteijn, W. M. (2012). Myofibroblasts in the Infarct Area: Concepts and Challenges. Microscopy and Microanalysis, 18(1), 35-49.

https://doi.org/10.1017/S143192761101227X

Document status and date:

Published: 01/02/2012

DOI:

10.1017/S143192761101227X

Document Version:

Publisher's PDF, also known as Version of record

Document license:

Taverne

Please check the document version of this publication:

- A submitted manuscript is the version of the article upon submission and before peer-review. There can be important differences between the submitted version and the official published version of record.

People interested in the research are advised to contact the author for the final version of the publication, or visit the DOI to the publisher's website.

- The final author version and the galley proof are versions of the publication after peer review.

- The final published version features the final layout of the paper including the volume, issue and page numbers.

Link to publication

\footnotetext{
General rights rights.

- You may freely distribute the URL identifying the publication in the public portal. please follow below link for the End User Agreement:

www.umlib.nl/taverne-license

Take down policy

If you believe that this document breaches copyright please contact us at:

repository@maastrichtuniversity.nl

providing details and we will investigate your claim.
}

Copyright and moral rights for the publications made accessible in the public portal are retained by the authors and/or other copyright owners and it is a condition of accessing publications that users recognise and abide by the legal requirements associated with these

- Users may download and print one copy of any publication from the public portal for the purpose of private study or research.

- You may not further distribute the material or use it for any profit-making activity or commercial gain

If the publication is distributed under the terms of Article $25 \mathrm{fa}$ of the Dutch Copyright Act, indicated by the "Taverne" license above, 


\title{
REVIEW ARTICLE
}

\section{Myofibroblasts in the Infarct Area: Concepts and Challenges}

\author{
Evangelos P. Daskalopoulos, Ben J.A. Janssen, and W. Matthijs Blankesteijn* \\ Department of Pharmacology, Cardiovascular Research Institute Maastricht, Maastricht University, \\ 50 Universiteitssingel, 6229ER Maastricht, P.O. Box 616, 6200MD Maastricht, The Netherlands
}

\begin{abstract}
Myofibroblasts are differentiated fibroblasts that hold a key role in wound healing and remodeling following myocardial infarction (MI). A large repertoire of stimuli, such as mechanical stretch, growth factors, cytokines, and vasoactive peptides, induces myofibroblast differentiation. Myofibroblasts are responsible for the production and deposition of collagen, leading to the establishment of a dense extracellular matrix that strengthens the infarcted tissue and minimizes dilatation of the infarct area. In addition, cells contributing to fibrosis act on sites distal from the infarct area and promote collagen deposition in noninfarcted tissue, thus contributing to adverse remodeling and consequently to the development of congestive heart failure (CHF). Current drugs that are used to treat post-MI CHF do influence fibroblasts and myofibroblasts; however, their therapeutic efficacy is far from being regarded as ideal. Novel therapeutic agents targeting (myo) fibroblasts are being developed to successfully prevent the cardiac remodeling of sites remote from the infarct area and therefore hinder the establishment of CHF. The purpose of this review article is to discuss the basic concepts of the myofibroblasts' actions in cardiac wound healing processes, factors that influence them, currently available pharmacological agents, and future challenges in this area.
\end{abstract}

Key words: heart, fibroblast, myofibroblast, myocardial infarction, cardiac remodeling, fibrosis, heart failure

\section{INTRODUCTION}

The normal adult heart is comprised of cardiac myocytes, making approximately $75 \%$ of the tissue volume, and noncardiomyocytes. However, cardiomyocytes are the minority of the cell population of the heart; nonmyocyte cells outnumber them and exact numbers vary between species. The cardiac fibroblasts are the predominant nonmyocyte cells, with endothelial and vascular smooth muscle cells existing in smaller proportions (Nag, 1980; Camelliti et al., 2005; Baudino et al., 2006). The interplay among these cells is extremely important for the developing heart, as well as for its normal function. Hence, factors that can affect the numbers and functioning of these cells can have major effects on the structure, physiology, and normal performance of the heart tissue (Baudino et al., 2006).

Until the late 1970s, cardiovascular research was focused only on the cardiomyocytes, and the significance of the nonmyocyte cells in the normal and pathological physiology of the heart was ignored. From then on, various research groups produced seminal research on the role of the fibroblasts (Zak, 1974; Nag, 1980) and myofibroblasts (Gabbiani et al., 1971) and defined them as critical and integral regulators of the cardiac heart function.

In this review article, we will give a detailed insight into the basic concepts and characteristics of the cardiac myofibroblast, including its origins, morphology, distribution,

Received June 1, 2011; accepted August 17, 2011

${ }^{\star}$ Corresponding author. E-mail: wm.blankesteijn@maastrichtuniversity.nl functions, and properties. We will also discuss its significance in the wound healing after a myocardial infarction (MI), the pathological remodeling, and its crucial role in the development of congestive heart failure (CHF). Lastly, we will summarize the effects of current pharmacological treatments of CHF on fibroblasts and myofibroblasts and the future promising challenges in this area.

\section{MYOCARDIAL InFARCTION AND WOUND HEALING}

Myocardial infarction is one of the leading causes of mortality and morbidity in the Western societies. According to a WHO report, cardiovascular diseases are the most important causes of death globally, and it was estimated that in 2004 alone coronary heart disease was the cause of approximately 7.2 million deaths worldwide (WHO, 2011). An infarct is the result of an occlusion of a coronary artery, due to a thrombus or a ruptured atheromatous plaque; blood flow to the affected region of the myocardium is inadequate - or even totally obstructed-and this can lead to ischemia and death of cardiomyocytes (Cleutjens et al., 1999). The extent of the damage to the myocardium depends on the location of the occlusion, on its severity, and the time taken for the artery to be re-perfused (by itself, by the use of thrombolytics, or by percutaneous coronary intervention) (Akasaka, 2010; Campbell \& Hilleman, 2010).

The wound healing of the infarcted myocardium is a dynamic process that comprises a series of events that consequently lead to the removal of the injured tissue and 
the establishment of a scar. Generally, the process of the cardiac wound healing in humans can be divided into four distinct phases. The loss of cardiomyocytes constitutes the first phase. Death of the myocytes occurs via necrosis (cell swelling, also known as oncosis) and apoptosis (cell shrinkage), with apoptotic death reaching a peak 6-8 h after an infarct in humans, as well as in rats (Cleutjens et al., 1999). Adult cardiomyocytes do not have the ability to divide or recuperate, and so the substitution of lost myocytes after the infarction is very limited at best (Soonpaa et al., 1995).

Necrosis causes intracellular constituents of myocytes to leak, and this induces the initiation of exudative inflammation (Buja \& Vela, 2008), which is the second phase of wound healing. The acute inflammatory phase occurs approximately $12-16 \mathrm{~h}$ after an infarct in a human heart and is defined by the up-regulation of a vast amount of cytokines and chemokines (e.g., Interleukin- $1 \beta$ [IL- $1 \beta]$, Interleukin-6 [IL-6], Interleukin-8 [IL-8], Interleukin-18 [I-18], Tumor Necrosis Factor- $\alpha[$ TNF- $\alpha]$, etc.), as well as adhesion molecules (e.g., ICAM-1, E-selectin) (Dewald et al., 2004; Dobaczewski et al., 2006; Frantz et al., 2009). The infarct area is infiltrated by polymorphonuclear leukocytes (or granulocytes) that exhibit a dual function: they remove dead cardiomyocytes and debris and also attract other types of inflammatory cells in the area, such as lymphocytes and macrophages. Peak numbers of granulocytes are reached approximately $48 \mathrm{~h}$ after an infarct in humans, while this occurs earlier in mice (Cleutjens et al., 1999; Dewald et al., 2004). The inflammatory cells that infiltrate the area (neutrophils, monocytes/macrophages) release proteolytic enzymes and reactive oxygen species that lead to a secondary "wave" of cardiomyocyte death (Nahrendorf et al., 2010).

The third phase of the healing of the injured myocardium is defined by the deposition of granulation tissue (Cleutjens et al., 1999). The trigger for the initiation of this phase is the release of anti-inflammatory cytokines, such as Transforming Growth Factor- $\beta$ (TGF- $\beta$ ). The latter is a key player in this stage because it diminishes the adhesive action of the inflammatory cells and stimulates the fibroblasts to differentiate into myofibroblasts (Rosenkranz, 2004). Its importance will be discussed in more detail later in this review article. During this stage, mesenchymal cells infiltrate the area and myofibroblasts start surrounding the infarcted area and deposit extracellular matrix (ECM). The deposition of ECM aims to retain the structural support and morphology of the cardiac tissue (Dobaczewski et al., 2006). Another characteristic phenomenon taking place during the third phase of the wound healing is the neovascularization of the infarct area. The formation of new vessels develops within a few days after an infarct, and its goal is to assist the reperfusion of the injured site with blood (Ren et al., 2002; Dewald et al., 2004; van der Laan et al., 2009). The granulation tissue phase can extend for approximately 1 to 2 months in humans while it lasts only for a few weeks in murine myocardium (Cleutjens et al., 1999).

Finally, the fourth stage of the cardiac tissue healing is characterized by the maturation of the granulation tissue into a stabilized scar. The reconstructed fibrotic tissue is rich in ECM and fibroblast-like cells, but there is rarely any presence of inflammatory cells approximately 1 month after the infarction (Dewald et al., 2004; Dobaczewski et al., 2006). Myofibroblast numbers start decreasing after the 7 th day post-reperfusion (Dobaczewski et al., 2006). However, a study in human MIs demonstrated that myofibroblasts may persist in the area even up to 17 years after the infarction (Willems et al., 1994). Early removal (e.g., due to apoptosis) of the fibroblast-like cells usually leads to poor healing of infarcts; hence, the persistence of the myofibroblasts in the infarct area is of vital importance (van den Borne et al., 2010).

Infarct healing and myofibroblast content appear to be genetically controlled. Recently, we demonstrated substantial differences between the cardiac remodeling of five different mouse strains. The number of myofibroblasts present in the scar post-MI was negatively associated with end diastolic volume (EDV) and ejection fraction (EF). These results confirmed that myofibroblasts counteract the dilatation of the infarct area and so restrict the development of CHF (van den Borne et al., 2009b).

\section{Fibroblasts, Myofibroblasts, AND Their Role in Wound Healing}

Fibroblasts are cells of mesenchymal origin that produce connective tissue and are found in a wide range of tissues of all vertebrates. They are flat, spindle-shaped cells with an elliptical-shaped nucleus (Camelliti et al., 2005), a large Golgi apparatus, and an extended rough endoplasmic reticulum (Souders et al., 2009). One of their characteristics is that they show extensive heterogeneity in phenotypes depending on the tissue, but studies in the lung and skin have shown that they are heterogeneous even within the same anatomical site, depending on the condition (physiological or nonphysiological) (Fries et al., 1994; Sorrell \& Caplan, 2004). Fibroblasts have no specific cellular markers; hence, their identification in histological studies is not an easy task (Souders et al., 2009). Their activated forms are the myofibroblasts, which are normally not found in the healthy adult heart (Sun \& Weber, 1996).

Myofibroblasts do not originate solely from pre-existing locally present fibroblasts that differentiate into the activated form. Myofibroblasts have been shown to arise through various other processes (Fig. 1), such as via endothelialmesenchymal transition (Zeisberg et al., 2007) and epithelialmesenchymal transition (Potts \& Runyan, 1989). Moreover, myofibroblasts can originate from fibrocytes or pericytes. The first are bone-marrow-derived cells that have extensive structural and functional similarities to the myofibroblasts (Bellini \& Mattoli, 2007). Circulating fibrocytes can respond to TGF- $\beta$, endothelin-1 (ET-1), or various interleukin signals and undergo differentiation into myofibroblasts (Strieter et al., 2009). On the other hand, pericytes are extensively branched cells that are located in capillaries and other small blood vessels. Pericytes can dissociate from the walls of the 


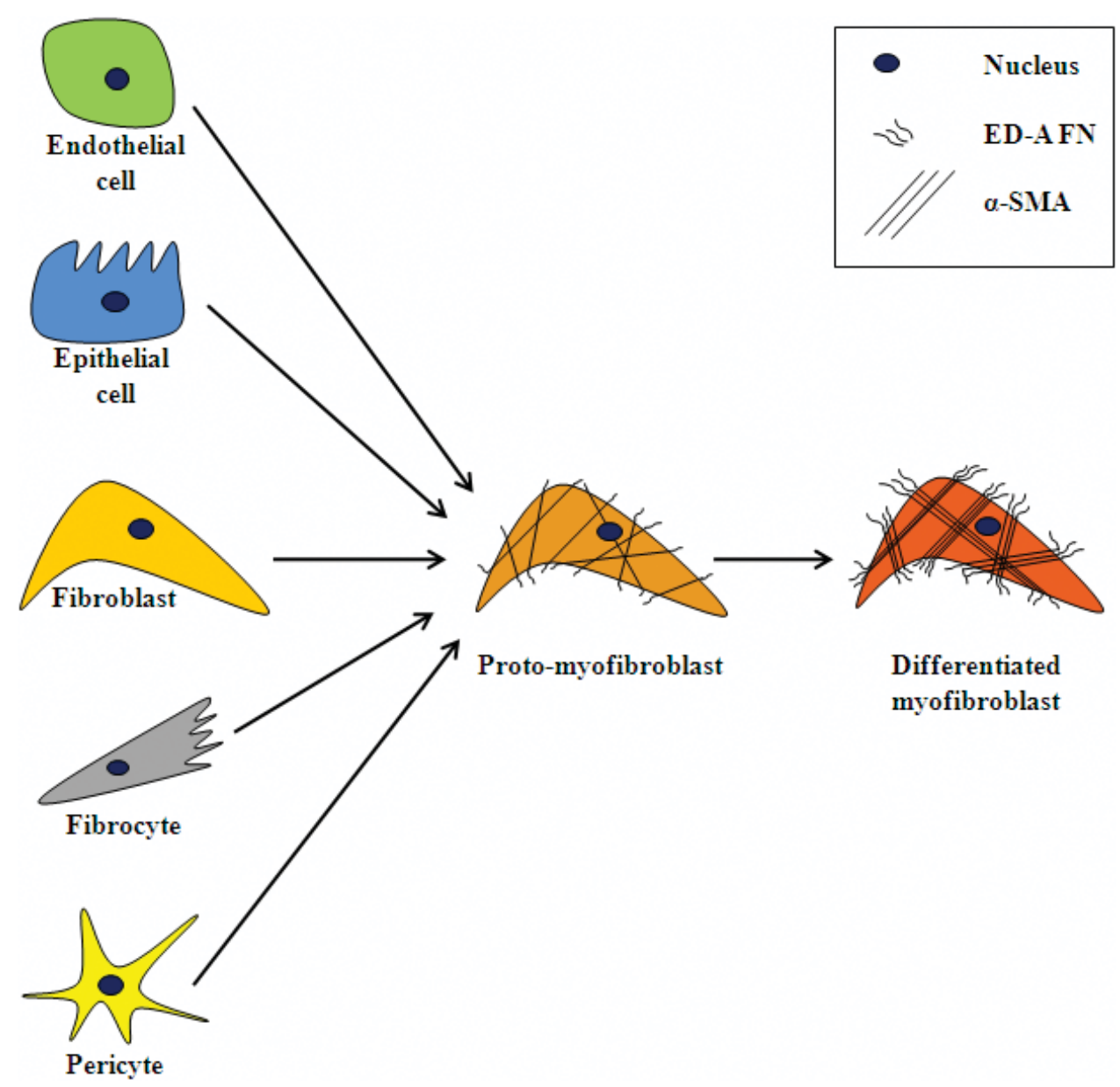

Figure 1. The myofibroblast precursors. In response to specific stimuli, a wide range of cells can undergo differentiation. Myofibroblasts originate mostly from resident fibroblasts, but also from epithelial cells (epithelial-mesenchymal transition), endothelial cells (endothelial-mesenchymal transition), or fibrocytes (mesenchymal progenitors). These cells first differentiate into an intermediate form (proto-myofibroblast) and under the influence of sustained mechanical stress, TGF- $\beta 1$, and/or fibronectin ED-A, the intermediate fibroblast differentiates to the activated myofibroblast. TGF- $\beta 1$, transforming growth factor $\beta 1$; fibronectin ED-A, fibronectin extra-domain $\mathrm{A}$.

blood vessels, migrate, and differentiate into the myofibroblast phenotype (Diaz-Flores et al., 2009). At present, the contribution of the different precursor cells to the actual myofibroblast population in the infarct area is far from clear.

Under physiological conditions, fibroblasts maintain the structure of the heart tissue by balancing the production of ECM, ECM-degrading metalloproteinases (MMPs), and tissue inhibitors of metalloproteinases (TIMPs) (Porter \& Turner, 2009). Following MI and the injury that is associated, fibroblasts differentiate into the proto-myofibroblast form and then to myofibroblasts (Hinz \& Gabbiani, 2003; Baum \& Duffy, 2011). The transition from the fibroblast to the proto-fibroblast phenotype is mainly driven by mechanical tension in the ECM. The main characteristics of the proto-myofibroblast phenotype (not present in fibroblasts) are the increased expression of fibronectin (especially the splice variant with the extra-domain A [ED-A] module) and the presence of mature focal adhesions. Proto-myofibroblast focal adhesions contain $\beta$ - and $\gamma$-actin microfilaments that are associated with nonmuscle myosin; however, these intermediate cells do not express $\alpha$-smooth muscle actin $(\alpha$ SMA) (Meran \& Steadman, 2011). Under the influence of sustained mechanical tension and the presence of TGF- $\beta$, proto-fibroblasts eventually differentiate into mature myofibroblasts. The differentiated myofibroblasts are characterized by the de novo expression of $\alpha$-SMA (Wang et al., 2006), which increases their contractibility (Hinz et al., 2001), and the increased expression of ED-A fibronectin and hyper-mature focal adhesions (Tomasek et al., 2002).

Myofibroblasts are responsible for the "fine-tuning" of the collagen turnover and have been proven to possess a key role in the wound healing and remodeling process that follows an ischemic episode, such as MI (Porter \& Turner, 2009). They are attracted to the infarct area by a variety of factors and start producing a precursor of collagen, called pro-collagen, which is transformed into its active form (collagen, mainly types I and III) with the aid of procollagen proteinases (Prockop \& Kivirikko, 1995). Collagen, along with various proteins, such as fibronectin, proteogly- 

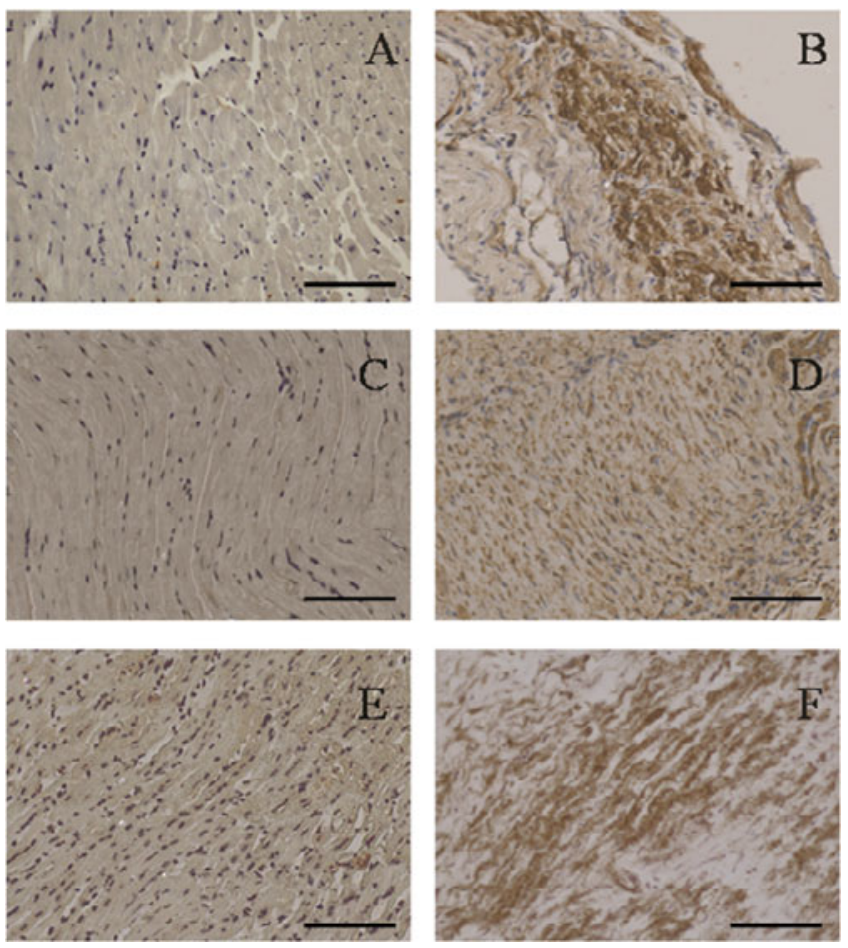

Figure 2. Microscopic images of $(\mathbf{A}, \mathbf{B})$ mouse, $(\mathbf{C}, \mathbf{D})$ rat, and (E, F) pig myocardium. Binding of the $\alpha$-SMA antibody (SigmaAldrich, St. Louis, MO, USA), signifying $\alpha$-SMA expression from myofibroblasts. Panels A, C, and E correspond to sections taken from noninfarcted areas, while panels $\mathbf{B}, \mathbf{D}$, and $\mathbf{F}$ are sections from infarcted areas (14 days post-MI). The pig heart sections were kindly provided by D.J. Duncker (Erasmus Medical Center, Rotterdam, The Netherlands). Scale bar $=100 \mu \mathrm{m}$; MI, myocardial infarction; $\alpha$-SMA, $\alpha$-smooth muscle actin.

can, elastin, matricellular proteins, cytokines, growth factors, proteases, etc., constitute the ECM (Holmes et al., 2005; Fomovsky et al., 2010; Matsui et al., 2010). These components form a three-dimensional matrix that serves crucial purposes, such as filling the spaces that the dead cardiomyocytes left void and so maintaining the architecture of the cardiac tissue and developing the scar that will heal the wound. Moreover, the ECM transmits chemical, mechanical, and electrical signals between the myocyte and nonmyocyte cells of the injured heart tissue (Holmes et al., 2005). ECM is deposited first in the border zone (located between infarcted and noninfarcted area) and then in the center of the infarct (Fig. 2) (van den Borne et al., 2009a). The increased deposition of collagen is regarded as a key adaptive response of the heart tissue to the cardiac injury. The infarction initiates a series of complex paracrine/ hormonal responses that lead to changes in the composition and structure of the collagen network of the heart tissue, leading to fibrosis of the infarct area. An overview of the characteristic functions of the myofibroblast can be found in Figure 3.

A broad spectrum of stimuli can activate the myofibroblasts: mechanical, electrophysiological, chemical, and miscellaneous stimuli.

\section{Mechanical Stimuli}

The myofibroblasts detect mechanical stimuli and respond immediately by ECM production and deposition. Cyclic mechanical stretch causes an increase in the expression of Collagen I and III (Husse et al., 2007). Other ECM proteins, such as proteoglycans, elastin (Fomovsky et al., 2010), cytokines, and growth factors, are also affected. It seems that the orientation of the collagen fibers is closely connected to mechanical stretch and determines the resistance of the myocardial scar. When large forces are applied during ventricular systole, a poorly-healed scar faces the risk of rupturing (van den Borne et al., 2009a). Myocardial scar tissue that demonstrates anisotropy (i.e., unevenly orientated ECM fibers and myofibroblasts) correlates with myocardial tissue that is more resistant to mechanical stretching. Hence, anisotropic scars have better chances of preserving the function of the ventricle chambers (Holmes et al., 1997; Fomovsky \& Holmes, 2010).

\section{Electrophysiological Stimuli}

An important feature of myofibroblasts (as well as their "silent" forms the fibroblasts) is that they are nonexcitable cells; hence, they cannot conduct an impulse. They form junctions with other myofibroblasts and other cells such as cardiomyocytes. These myofibroblast gap junctions are composed of Connexins (Cx43 and $\mathrm{Cx} 45$ ), which show structural differences compared to their cardiomyocyte counterparts. Fibroblasts were found to express the nonphosphorylated Cx43 form $(41 \mathrm{kDa})$, whereas cardiomyocytes seem to express mainly the phosphorylated Cx43 form (44-46 $\mathrm{kDa}$ ). Cx45 also shows molecular weight differences between fibroblasts and cardiomyocytes; however, this discrepancy is probably not due to phosphorylation status. The levels of $\mathrm{Cx} 43$ seem to directly affect the proliferation of fibroblasts, with increased $\mathrm{Cx} 43$ expression causing suppressed proliferation of the myofibroblasts and vice versa (Zhang et al., 2008). Moreover, 40 years ago it was demonstrated by Hyde et al. (1969) that fibroblasts co-cultured with cardiomyocytes in vitro form junctions and impulse propagation is delayed. In the fibrotic heart, ECM and myofibroblasts lie between cardiomyocytes. The expansion of ECM creates gaps between cardiomyocytes, which may lead to conductivity problems and consequently lifethreatening arrhythmias (Rohr, 2009; Pellman et al., 2010). However, the establishment of serious arrhythmias is a more complicated procedure, based not only on electrical but also structural and contractile changes in the heart (Pellman et al., 2010).

\section{Chemical Stimuli}

A wide repertoire of chemical stimuli can activate the myofibroblasts, including growth factors (e.g., TGF- $\beta$ ), vasoactive peptides (e.g., Ang-II, ET-1), cytokines (e.g., TNF- $\alpha$, interleukins), and others. TGF- $\beta$ is a multifunctional growth factor, critical for cell proliferation, migration, differentiation, and apoptosis (Tomasek et al., 2002). Its great importance is stressed by a study showing that approximately $50 \%$ 


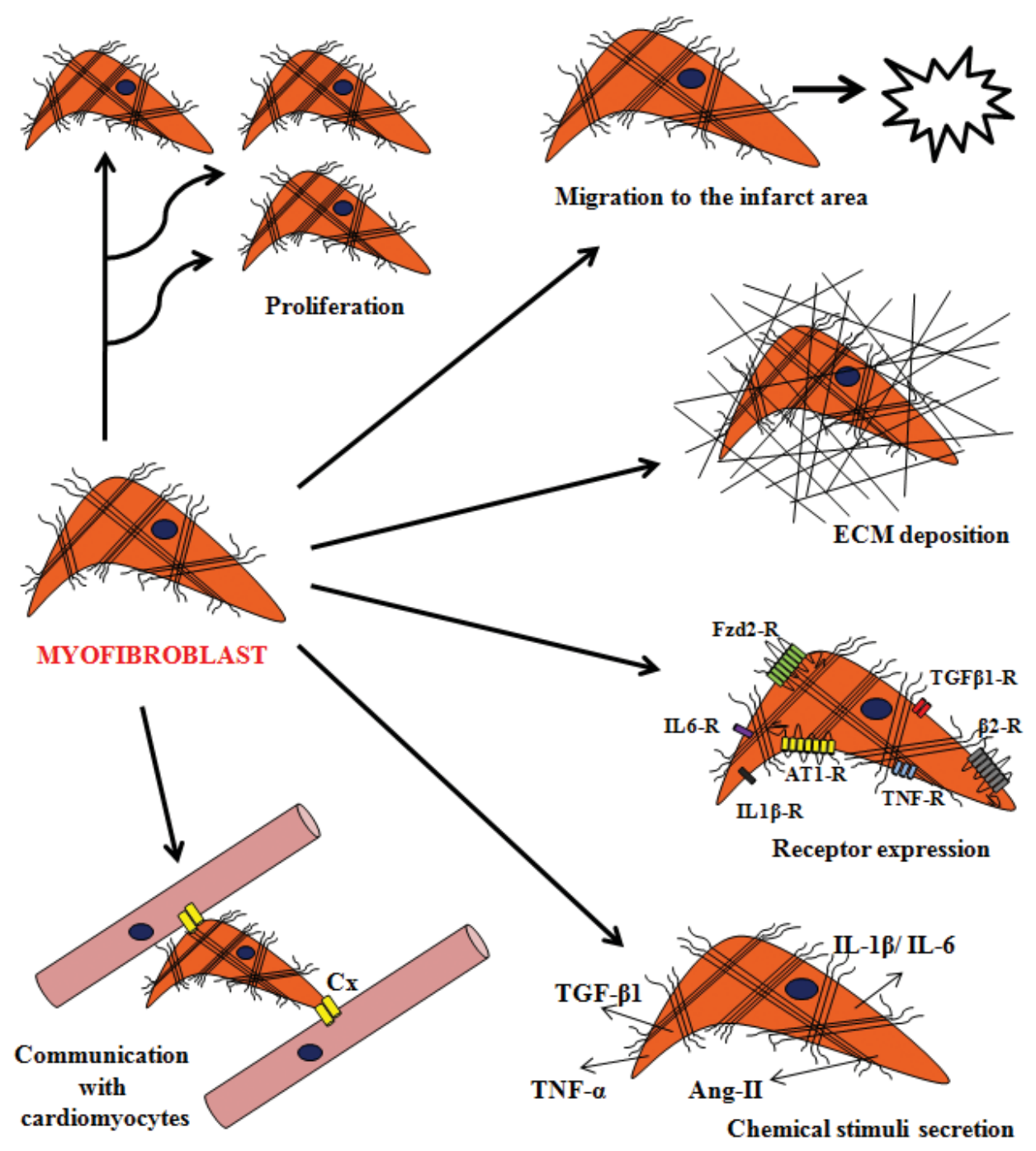

Figure 3. Functions of the differentiated myofibroblast. The activated myofibroblast can proliferate, migrate to the infarct area, deposit collagen and ECM proteins, communicate with other cells such as cardiomyocytes, express a variety of receptors (Fzd2-R, AT1-R, $\beta 2$-R, TGF- $\beta 1$-R, TNF-R1/2, IL-R), and secrete various stimuli (Ang-II, TGF- $\beta 1$, TNF- $\alpha$, IL-6/1 $\beta$ ). Because of this broad spectrum of functions, the myofibroblast constitutes the center of the healing process following MI. ECM, extracellular matrix; Fzd2-R, frizzled-2 receptor; AT1-R, angiotensin-1 receptor; $\beta 2-\mathrm{R}, \beta 2-$ adrenergic receptor; TGF $\beta 1-\mathrm{R}$, transforming growth factor $\beta 1$ receptor; TNF-R, tissue necrosis factor receptor; IL6-R, interleukin-6 receptor; IL1 $\beta$-R, interleukin- $1 \beta$ receptor; Ang-II, angiotensin-II; TGF- $\beta 1$, transforming growth factor $\beta 1$; TNF- $\alpha$, tissue necrosis factor $\alpha$; IL-1 $\beta /$ IL-6, interleukin- $1 \beta /$ interleukin-6; Cx, connexins.

of TGF- $\beta 1$ knockout mice die before birth, due to improper hematopoiesis and vascular development (Dickson et al., 1995). Three genes expressing TGF- $\beta$ exist (TGF- $\beta 1$, TGF$\beta 2$, and TGF- $\beta 3$ ), with TGF- $\beta 1$ being the predominant form. It acts on two different types of receptors, activin receptor-like kinase 1 (ALK1) and activin receptor-like kinase 5 (ALK5). The downstream effectors of TGF- $\beta$ are proteins called Smad. When TGF- $\beta$ acts on its receptors, Smads become activated, form complexes, translocate into the cell nucleus, and modulate gene expression (Leask \& Abraham, 2004; Hinz, 2007; Dobaczewski et al., 2011). In the cardiac tissue, TGF- $\beta$ is regarded as the most important regulator of the fibrotic response after MI. It modulates the proliferation and migration of fibroblasts and stimulates the fibroblast-to-myofibroblast differentiation (Tomasek et al., 2002; Bujak \& Frangogiannis, 2007; Hinz, 2007; Dobaczewski et al., 2011). An interesting observation is that TGF- $\beta 1$ seems to suppress proliferation of fibroblasts in humans, rats, and rabbits but has the opposite effect in mouse fibroblasts (Porter \& Turner, 2009). Additionally, it facilitates ECM deposition in a triple fashion: it enhances collagen secretion, it suppresses the MMPs (which degrade collagen), and also induces tissue inhibitors of metalloproteinases (TIMPs), which inhibit MMP activity. Lastly, TGF- $\beta$ has a direct effect on the connective tissue growth factor (CTGF), an effect that also instigates fibrosis development (Dobaczewski et al., 2011).

Ang-II and the renin-angiotensin system (RAS) as a whole have been implicated in the modulation of the fibroblasts and the cardiac remodeling. Angiotensin converting 
enzyme (ACE) and the angiotensin II receptors, type 1 (AT1 receptors) are actively expressed by myofibroblasts during the fibrotic repair following MI (Sun \& Weber, 1996). Ang-II promotes the proliferation and differentiation of fibroblasts and mediates ECM deposition, and this seems to be controlled via AT1 receptors, while a direct link between Ang-II and TGF- $\beta 1$ is hypothesized (Sun et al., 1998; Lijnen et al., 2001; Rosenkranz, 2004). Administration of drugs that prohibit Ang-II signaling (ACE inhibitors and AT1-receptor antagonists) after MI are associated with suppressed TGF- $\beta$ levels (Sun et al., 1998; Yu et al., 2001).

A broad range of cytokines, such as interleukins and TNF- $\alpha$, affects the fibroblast directly. Interleukin-6 (IL-6) is implicated in cell growth, differentiation, and apoptosis and has been shown to be present in cardiac fibroblasts, as well as in myocytes (Banerjee et al., 2009). IL-6 enhances fibroblast proliferation but has a negative action on collagen deposition because it reduces synthesis of collagen I and III and induces the secretion of MMPs (Siwik et al., 2000). Abnormally high levels of circulating IL-6 can have a direct effect on cardiac fibrosis, and the soluble IL-6 receptor (sIL-6R) is fundamental for the increased collagen deposition by cardiac fibroblasts, as well as the cardiac fibroblastto-myofibroblast differentiation (Dixon, 2010; Melendez et al., 2010). Cardiotrophin-1 (CT-1), a member of the IL-6 cytokine family, has been shown to activate various signaling pathways, such as JAK/STAT, MAPK, and PI3K/Akt, and so to induce protein synthesis in fibroblasts (Freed et al., 2003). CT-1 presence initiates myofibroblast migration and proliferation, as well as stimulating migration and proliferation of nonmyocyte cells (fibroblasts and others) from the area surrounding the infarct scar, thus maintaining the repopulation of the scar area (Freed et al., 2005).

Interleukin-1 $\beta$ (IL-1 $\beta$ ) induces hypertrophy of cardiomyocytes, but it suppresses the proliferation of rat cardiac fibroblasts (Palmer et al., 1995). It also has a profound anti-fibrotic effect by causing elevated MMP expression and suppression of collagen deposition (Siwik et al., 2000). Its complex character is confirmed by the modulatory effect of IL- $1 \beta$ on RAS, as it increases the expression of the AT1 receptor (Gurantz et al., 2005). On the other hand, interleukin- $1 \alpha$ (IL- $1 \alpha)$ is another pro-inflammatory cytokine that is found elevated in the heart post-MI. Two studies by the group of Turner et al. on cultured human myofibroblasts have shown that IL- $1 \alpha$ stimulates the expression of IL- $1 \beta$, IL-6, and TNF- $\alpha$ (Turner et al., 2009), while it instigates the expression of four different MMPs and also the expression of TIMP-1 in human cultured myofibroblasts (Turner et al., 2010).

Additionally, interleukin-17 (IL-17) and interleukin-18 (IL-18) also exhibit a modulatory effect on the cardiac fibroblast. IL-18 seems to cause a significant increase in the collagen deposition, while it induces proliferation and migration of rat cardiac fibroblasts exposed to it (Fix et al., 2011). On the contrary, IL-17 induces primary cardiac fibroblast migration and modulates MMP expression; hence, it seems to be important for the fibrosis that follows a myocardial insult (Cortez et al., 2007). Finally, the data for interleukin-10 (IL-10) are conflicting because in one study it was shown that IL-10 does not seem to play a role in deposition of ECM after MI (Zymek et al., 2007), while a more recent study demonstrates that IL-10 can suppress the inflammatory response and have anti-fibrotic effects (Krishnamurthy et al., 2009).

TNF- $\alpha$ is a pro-inflammatory cytokine that is expressed in the human cardiac fibroblast. According to Porter et al. (2004a), TNF- $\alpha$ induces the expression, the proliferation, and the migration of various MMPs. Its suppressive effect on the ECM deposition is also reported by Siwik et al. (2000) in an in vitro study involving rat cardiac fibroblasts. In the same way with IL- $1 \beta$, TNF- $\alpha$ is involved in the control of the RAS, and this is done by an enhancing action on rat AT1 receptors (Gurantz et al., 2005).

\section{Miscellaneous Stimuli}

Fibronectin is one of the main ECM components. When an ED-A module is inserted into the fibronectin structure, the latter is transformed into the ED-A fibronectin (ED-A FN) splice variant. This splice variant exhibits increased adhesive properties and allows adhesion between fibronectin and the cells of the cardiac tissue. This is crucial for the TGF- $\beta$ mediated fibroblast-to-myofibroblast differentiation (Manabe et al., 1997; Serini et al., 1998). Further, hyaluronan (HN) is a glucosamine that utilizes CD44 in order to associate with cells (Ponta et al., 2003). A blockade of HN in fibroblasts inhibits the $\alpha$-SMA expression during the differentiation of the myofibroblasts, and this implies that $\mathrm{HN}$ is essential for the maintenance of the myofibroblast phenotype (Webber et al., 2009). Lastly, osteopontin (OPN) is regarded as an important protein that is involved in the wound healing process post-MI. The expression of OPN is induced in murine infarcts but also in sites remote from the infarct area (Trueblood et al., 2001), and it appears to modulate differentiation and activity of myofibroblasts. Thus it has a fundamental role in the myocardial remodeling after a myocardial injury (Lenga et al., 2008).

\section{Adverse Myocardial Remodeling and the Development of Congestive Heart FAILURE}

Congestive heart failure is one of the most serious health burdens for western societies. The prevalence in the United States is over 5.8 million, while there are more than 23 million patients suffering all over the world. Lifetime risk of developing heart failure at the age of 40 years is close to $20 \%$ in both men and women (Bui et al., 2011). According to the latest American Heart Association Report, survival for patients with a CHF diagnosis has improved in the last years; however, the mortality rate remains high; approximately 1 in 2 patients diagnosed with CHF dies within 5 years. It is characteristic that in the year 2007 , about $11 \%$ of the total deaths $(277,193$ deaths) in the United States involved heart failure. The cost for the treatment and manage- 
ment of patients diagnosed with CHF is also a serious issue-in 2007, more than 3 million patients were hospitalized in the United States (Roger et al., 2011), and the total cost due to CHF admissions was U.S.\$39 billion per year (Bui et al., 2011). As reported in a study by Wexler et al. (2001), more than 4 in 10 patients first diagnosed with CHF were readmitted within 6 months, with each admission costing more than U.S.\$7,000 per patient to the U.S. health care system. One of the major causal factors of CHF is myocardial infarction (McMurray \& Pfeffer, 2005).

The healing process of the injured myocardium is a phenomenon that causes drastic molecular, structural, and functional alternations in the area of the infarct, as well as in areas remote from the infarct site (noninfarcted left ventricle $[\mathrm{LV}]$ or even right ventricle $[\mathrm{RV}]$ ) (Cleutjens et al., 1999). Pathologic ventricular remodeling is associated with the activation of a plethora of neuroendocrine, paracrine, and autocrine factors, such as the renin-angiotensinaldosterone system (RAAS), the adrenergic nervous system, increased oxidative stress, inflammatory cytokines and chemokines, immune response cells (neutrophils), macrophages, ET-1, etc. (Frantz et al., 2009; Konstam et al., 2011). In the beginning, the remodeling of the ventricular wall is associated with changes in the architecture of the ventricles (increased chamber volume), which is an adaptive mechanism aiming to sustain the cardiac output at normal levels. The scar in the infarct area is elongated and becomes thin, allowing for the volume of the ventricular chamber to be augmented (Konstam et al., 2011). Later in the remodeling process, cardiomyocytes in the noninfarcted sites become hypertrophic and in some cases they might even double their size (Olivetti et al., 1994), something that leads to a decline in their performance (Konstam et al., 2011).

On the other hand, the irreversible fibrotic changes are not restricted in the infarct site, but also occur in areas that lie remotely of the infarct area. The replacement fibrotic tissue is characterized by deposition of collagen fibers with distorted cross-linking, which leads to stiffness of the cardiac muscle and to a gradually worsening cardiac performance (Beltrami et al., 1994). If left untreated, LV hypertrophy, ventricular dilatation, and the declining contractile ability due to fibrosis worsen progressively until the heart becomes unable to fulfill its function, and CHF develops (McMurray \& Pfeffer, 2005; Frangogiannis, 2006; van den Borne et al., 2010; Konstam et al., 2011).

\section{Current Therapy for Heart Failure}

Activation of the RAS has been extensively studied and has a key role in normal and abnormal cardiovascular function. The effector of this system is angiotensin II (Ang-II), which activates its own receptors, AT-1 and AT-2 (Kim \& Iwao, 2000). Cultured myofibroblasts obtained from infarct scar tissue are found to express angiotensinogen, ACE, and AT receptors (Katwa et al., 1997). This means that myofibroblasts have the ability to produce Ang-II de novo. Ang-II is secreted by the activated myofibroblasts and regulates colla- gen deposition and fibrosis of the myocardium (infarcted and noninfarcted), leading to adverse remodeling and eventually heart failure as mentioned in a previous section (Cleutjens et al., 1995). The use of ACEI or AT-1 receptor blockers in lab animals has been proven to attenuate this effect and reduce mortality and morbidity (Schieffer et al., 1994; Taylor et al., 1998). Moreover, a study by Yu et al. (2001) showed that treatment with AT1-receptor blockers and/or ACEI suppresses TGF- $\beta$ expression in the infarcted heart. A large number of seminal clinical trials in human patients using ACEI, AT1-receptor blockers, or the combination of the two have proven that targeting of Ang-II prevents the progression of the adverse remodeling of the heart tissue and reduces the overall mortality and morbidity following MI (SOLVD Investigators, 1991; Kober et al., 1995; McKelvie et al., 1999; McMurray et al., 2003; Pfeffer et al., 2003). The beneficial effect of the ACEI and the AT1-receptor blockers seems to be achieved via the maturation of the scar tissue in the infarct border zone, and the minimization of the ECM deposition in areas that are far from the infarct (van den Borne et al., 2008).

Another class of drugs also regarded as the gold standard in the treatment of CHF after MI is the $\beta$-adrenoceptor antagonists. Post-MI, the activity of the sympathetic system increases because there is loss of cardiomyocytes (hence, reduced cardiac output) and the blood supply of the various organs has to be maintained in physiological levels (Lefkowitz et al., 2000). The beta-adrenergic signaling pathway and its stimulation by catecholamines are the most important regulators of cardiac function (Post et al., 1999). Cardiomyocytes express mainly the beta1-adrenoceptor; however, the beta2-adrenoceptor is the predominant receptor type in cardiac fibroblasts (Meszaros et al., 2000). Beta2antagonism is found to inhibit fibroblast proliferation (Turner et al., 2003); however, the effect of the betaadrenergic pathways on the myofibroblast differentiation and the deposition of ECM has not been clarified yet (Porter \& Turner, 2009).

The mineralocorticoid aldosterone is part of the extended RAAS. The group of Brilla et al. has done extensive work on the mechanism connecting aldosterone and the cardiac fibroblasts. Increased levels of aldosterone were found to stimulate the proliferation of fibroblasts and induce the synthesis of collagen, which has an inductive effect on the interstitial fibrosis (Brilla et al., 1994; Brilla et al., 1995). Another study confirmed that aldosterone increases collagen type I synthesis in cardiac fibroblasts; however, it does not seem to cause degradation of collagen, something that is exhibited by Ang-II (Zhou et al., 1996). Moreover, high levels of aldosterone have a direct effect on the in vitro proliferation of human cardiac myofibroblasts, and this may lead to cardiac fibrosis (Neumann et al., 2002). Interestingly, a study on a rat model showed that low dose aldosterone, which was administered intrapericardially, increased the left ventricular epicardial interstitial collagen levels by more than $70 \%$. This change was not demonstrated by intravenous low dose aldosterone injection. However, when 
higher doses of aldosterone were administered, this pattern was reversed and intravenous infusion was the one that caused an enhancement of epicardial interstitial collagen levels in the LV, while intrapericardial infusion had no effect (Minnaard-Huiban et al., 2008). Two important clinical studies designed by Pitt et al. have provided evidence for the importance of aldosterone antagonism in the reduction of mortality and morbidity in patients with heart failure. The RALES study (Pitt et al., 1999) in which spironolactone (an aldosterone receptor blocker) was administered and the EPHESUS study (Pitt et al., 2003) in which eplerenone (a selective aldosterone blocker) was used-both in addition to the standard therapy (ACEI plus loop diuretic) — showed a substantial decrease in mortality and morbidity of patients suffering from heart failure.

Finally, the class of statins (HMG-CoA reductases) has lately been gaining more attention, as a useful co-treatment for patients suffering from CHF. Statins are licensed for use in hypercholesterolemia; however, experimental work has shown that they might have direct effects on fibroblasts and myofibroblasts-hence, they could assist in the treatment of CHF. In a study by Porter et al. (2004b), simvastatin suppressed the proliferation of human myofibroblasts. A study with cardiac fibroblasts from dogs that had been treated with simvastatin revealed that simvastatin decreased the fibroblast $\alpha$-SMA expression, and this was reversed when TGF- $\beta$ was administered. This observation implies that simvastatin can suppress the fibroblast-to-myofibroblast differentiation (Shiroshita-Takeshita et al., 2007). This could be an interesting challenge for the avoidance of fibrosis in areas remote from the infarct; however, this might cause reduced fibrosis in the infarct area, hence reduced healing in the infarct area, with detrimental effects (e.g., rupture of the infarct area).

\section{Future Opportunities for Heart FAILURE THERAPY}

Due to improved survival of patients after suffering a MI and the increase in the life expectancy of the population in the western world, it is estimated that the prevalence of heart failure will rise (Owan et al., 2006). It is apparent that the currently available drug therapies are quite successful in reducing mortality and morbidity; however, they cannot stop dilatation or cause regression of the adverse remodeling of the heart tissue once this has begun. On the other hand, they may cause significant side effects, which lead to noncompliant patients and consequently reduced efficacy of the therapies. Therefore, it is crucial that new, more effective means of treatment are discovered.

\section{Wnt/Frizzled-Pathway}

One fast-growing field of research involves the Wnt/frizzled (Wnt/Fzd) pathway in the regulation of myofibroblast actions. Since the discovery of the Wnt gene in the early 1980s by Nusse and Varmus (1982), the Wnt/Fzd signaling pathway has established its key role in many biological systems and various pathological states, especially in the heart
(Blankesteijn et al., 2008; van de Schans et al., 2008). Seminal studies such as the one from McMahon and McMahon (1989) proved that the murine irp gene (later renamed to $W n t-2$ ) is expressed in the heart tissue, while previous studies performed in our laboratory (Blankesteijn et al., 1997) associated the Fzd-2 receptor with the myofibroblast actions post-MI and stressed its importance during the healing process after an infarction. More recent studies demonstrate that secreted frizzled related protein 2 (SFRP2) — which is a Wnt and Fzd modulator-reduces the collagen deposition (He et al., 2010). There is strong evidence that the largest portion of the myofibroblasts present in the infarcted area is of endothelial-mesenchymal-transition descent. It was demonstrated that this transition is mediated by the canonical Wnt signaling, hence playing a key role in the fibrosis of the infarcted tissue (Aisagbonhi et al., 2011). Lastly, Wnt3a upregulates TGF- $\beta$ expression via the canonical pathway ( $\beta$ catenin) and so enhances significantly the differentiation of the myofibroblast (Carthy et al., 2011).

An in vitro study by our group showed that manipulations in the Wnt/Fzd signaling can induce myofibroblast migration and differentiation, while it stressed that various combinations of Fzd receptors ( $\mathrm{rFzd}-1$ or $\mathrm{rFzd}-2$ ) and Wnt ligands (Wnt3a or Wnt5a) exert distinct effects (Laeremans et al., 2010). Further studies in this area involving in vitro data indicate that a peptide fragment of Wnt5a (named UM206) acts as an antagonist for the Fzd-1/2 receptor and can fully reverse the inhibitory effect of Wnt3a on fibroblast migration and differentiation. Moreover, in a recent study, in vivo administration of UM206 for 5 weeks in a MI mouse model-started directly after the MI induction-showed impressive results: UM206 upregulated myofibroblast numbers in the infarct area, lowered collagen production and the expansion of the fibrosis increased neovasculogenesis, while cardiac function markers (EDV, EF) were improved and death due to heart failure was completely prevented (compared to approximately $35 \%$ mortality after 5 weeks post-MI in the control group) (Fig. 4) (Laeremans et al., 2011). All this information strengthens the hypothesis that blockade of the Wnt/Fzd signaling pathway can serve as a novel and promising therapeutic approach to prevent cardiac remodeling and heart failure after MI.

\section{TGF- $\beta$ Pathway}

As mentioned in a previous section, the growth factor TGF- $\beta 1$ is upregulated in MI and cardiac hypertrophy and is the key regulator in the process of the adverse cardiac remodeling and fibrosis. So, TGF- $\beta$ and its signaling pathway could be interesting targets in the search of novel treatment agents against remodeling of the cardiac tissue (Ellmers et al., 2008; Dobaczewski et al., 2011). One study group demonstrated that the-late in the healing process - in vivo blockade of the ALK5 receptor of TGF- $\beta$ reduced significantly the remodeling following MI (Tan et al., 2010). TGF- $\beta$ is involved in the beneficial early phase post-MI (wound healing), as well as the harmful late phase of the fibrosis in areas remote from the infarct. Hence, blocking 


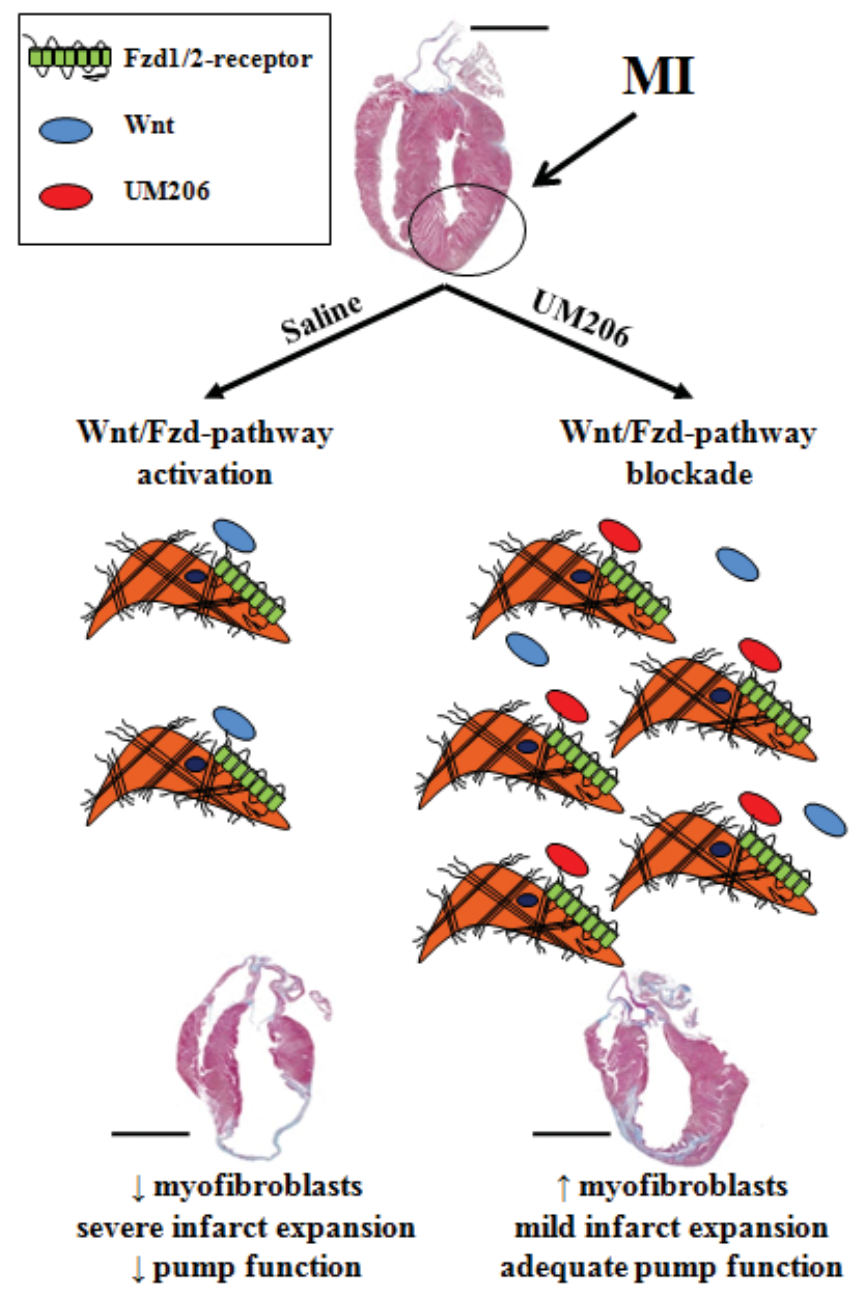

Figure 4. Wnt/Fzd-signaling pathway involvement in the cardiac remodeling ( 5 weeks post-MI) in a coronal view of mouse heart. Blockade of Fzd1/2-receptors with UM206 after induction of MI increases myofibroblast numbers and leads to reduced infarct expansion and improved cardiac function. Treatment with saline allows activation of the Wnt/Fzd-pathway, which gives rise to diminished myofibroblast presence, expansion of infarct area, and worsening of cardiac function markers. Scale bar $=3 \mathrm{~mm}$; MI, myocardial infarction; Fzd1/2-receptors, frizzled1/2-receptors.

TGF- $\beta$ early in the infarct healing process might have detrimental effects on the matrix degradation, leading to incompletely healed infarcts and cardiac dilatation. This was exhibited by the group of Frantz et al. (2008) that used an anti-TGF- $\beta$ antibody and showed that total block of TGF- $\beta$ aggravates left ventricular remodeling and increases mortality in mice. Inhibiting TGF- $\beta$ only in the late phase allows the inflammatory phase to be completed normally, while unwanted remodeling in the remote areas is avoided. Moreover, TGF- $\beta 1$ can activate another type of receptor, the ALK1. The activated type I receptors mediate their effects via phosphorylation of the Smad proteins, with Smad3 being of special importance (Dobaczewski et al., 2011). A study by Bujak et al. (2007) demonstrated interesting findings, documenting that myofibroblasts are found in greater numbers in Smad3-knockout mice compared to wild type; however, knockout animal hearts show decreased remodeling and less diastolic dysfunction. It seems that Smad3 absence prevents fibrosis in the noninfarcted myocardium and hence reduces the adverse effects of the cardiac remodeling (Bujak et al., 2007). A recent in vitro study by Dobaczewski et al. (2010) showed that the Smad3-knockout mouse fibroblasts are "mulfunctional," in the sense that they demonstrate decreased proliferation, migration, differentiation to myofibroblast phenotype, and $\alpha$-SMA expression. All this information suggests that the Smad3 pathway could be of great interest as a promising target for the prevention of cardiac fibrosis and remodeling by minimizing fibrosis and remodeling, while at the same time avoiding the harmful effects of the remote fibrosis.

Furthermore, it is known that endogenous inhibitors of TGF- $\beta$ exist and so they could be of importance to the hunt for novel heart anti-fibrotic agents. One of the TFG- $\beta$ inhibiting proteins is the c-Ski. This protein appears to inhibit TGF- $\beta$ via an effect on Smads (Akiyoshi et al., 1999). An in vivo experiment with Sprague-Dawley rats indicates that the $105 \mathrm{kDa}$ form of c-Ski expression is found significantly increased after a MI, compared to levels in shamoperated animals. Moreover, induction of c-Ski in an in vitro study of the same group demonstrated a significant depression of myofibroblast $\alpha$-SMA presence and deposition of collagen (type I), an effect that is associated to an inhibition of Smad2. Increased levels of c-Ski seem to inhibit the differentiation of fibroblasts to the myofibroblast phenotype, which can have a critical effect on the inhibition of fibrosis in the heart after a MI. Consequently, c-Ski could be suggested as a likely therapeutic approach against the cardiac remodeling (Cunnington et al., 2011).

\section{NOX4}

Another research area with a promising hypothesis as a potential target for pharmacological intervention in the prevention of adverse cardiac fibrosis is the NADPH oxidase (NOX). Seven different NOX genes are identified in the human genome (Sumimoto et al., 2005); however, only two seem to be expressed in cardiac fibroblasts and myofibroblasts, NOX2 and NOX4 (Cave et al., 2006). A study by Cucoranu et al. (2005) showed that NOX4 upregulates $\alpha$-SMA in human cardiac fibroblasts in response to TGF- $\beta 1$, and this is mediated via the $S \operatorname{mad} 2 / 3$ transcription factor activator. The activation of $S \operatorname{mad} 2 / 3$ enhances the differentiation of fibroblasts to myofibroblasts. Another study on a lung fibrosis mouse model demonstrated that the elimination of the NOX4 gene inhibits differentiation of myofibroblasts and consequently hinders fibrosis (Hecker et al., 2009). A close relationship seems to be in place among NOX4, TGF- $\beta 1$, and the cardiac myofibroblasts; however, more in vivo research is needed to ascertain whether manipulation of NOX4 could be used as a therapeutic approach to cardiac fibrosis.

\section{miRNAs}

Over the last years, miRNAs are gaining more and more interest as innovative therapeutic strategies in the treatment 
of various cardiovascular diseases. miRNAs are short (approximately 22-nucleotide) noncoding RNAs that control gene expression by either causing target mRNA degradation or blocking translation (Zhang, 2008). Various examples of miRNAs have been investigated, and some have been found to be very promising in the battle against cardiac fibrosis. A study by Thum et al. (2008) demonstrates that expression of miRNA- 21 is found to be increased in the fibroblasts in heart failure, something that seems to be mediated by increased MAPK. Moreover, mice that had undergone transverse aortic constriction (TAC) and then were treated with a miRNA-21 silencer (antagomiR-21) showed decreased fibrosis and minimized left ventricular dilatation. Hence, silencing of miRNA-21 could be of therapeutic interest (Thum et al., 2008). Another miRNA that might be of interest is miRNA-29. Its expression was found to be inhibited in the border zone of infarcted hearts. This could mean that upregulation of miR-29 may be a good candidate for MI therapy; however, the relationship is not clean-cut and more research is needed on the role of miRNA-29 (van Rooij et al., 2008). Lastly, two miRNAs - miRNA-30 and miRNA133-were shown to modulate the expression of CTGF and so lead to decreased expression and deposition of collagen fibers, while a depression in the levels of these two miRNAs seems to be connected directly to a rise in CTGF levels and so extensive fibrosis of the myocardium (Duisters et al., 2009). There is still much to be done in this area because miRNAs have not been tested in humans yet, and as a consequence our knowledge regarding potential side effects is still very limited.

\section{Endothelin-1}

Another field of interest in the battle against unwanted remodeling of the heart is endothelin-1 (ET-1). This is a vasoconstrictor peptide that is expressed in cardiac fibroblasts and myofibroblasts. It has been established that TGF- $\beta$ stimulates human lung fibroblasts via ET-1, and this in turn triggers $\alpha$-SMA and collagen production (Shi-wen et al., 2007). Studying the effect of diabetes mellitus on cardiac fibrosis, one group reported a stimulation of fibroblast emergence from endothelial cells (endothelial-to-mesenchymal transition), and this transition seems to be partially mediated by ET-1 (Widyantoro et al., 2010). In addition, $\mathrm{ET}_{\mathrm{A}}$ and $\mathrm{ET}_{\mathrm{B}}$ receptors are expressed in fibroblasts, and their activation leads to myofibroblast differentiation, increased ECM deposition, and MMP activity suppression (Guarda et al., 1993; Katwa, 2003). So, ET-1 seems to be a mediator in the development of excessive scarring and fibrosis; therefore, an agent acting as an $\mathrm{ET}_{\mathrm{A}} / \mathrm{ET}_{\mathrm{B}}$ receptor antagonist could be a useful means of halting the unwanted myocardial fibrosis (Rodriguez-Pascual et al., 2011). Animal studies showed that the blockade of $\mathrm{ET}_{\mathrm{A}}$ has protective effects following MI. Use of BQ123, a $\mathrm{ET}_{\mathrm{A}}$-selective antagonist improved survival and cardiac function in rats post-MI. The nonselective $\mathrm{ET}_{\mathrm{A}} / \mathrm{ET}_{\mathrm{B}}$ antagonist Bosentan also improved cardiac function and reduced dilatation. Early studies in humans demonstrated that both Bosentan and BQ123 can also be beneficial in the pe- riod after an infarction. However, the use of $\mathrm{ET}_{\mathrm{A}}$ blockade is of limited use, due to its adverse renal effects. ET-1 is secreted locally in the kidneys (causing diuresis and excretion of $\mathrm{Na}^{+}$), and total blockade could lead to fluid retention, increase the blood pressure, and prove detrimental (Rehsia \& Dhalla, 2010), an observation made in a study with $\mathrm{ET}_{\mathrm{A}} /$ $\mathrm{ET}_{\mathrm{B}}$ knockout mice (Ge et al., 2008). As a conclusion, further studies are required in order to elucidate the ET antagonistrelated adverse effects, as well as the overall beneficial effect of ET antagonism in humans.

\section{Biglycan and Relaxin}

Two new promising targets are biglycan and relaxin. Treatment of primary cardiac fibroblasts with TGF- $\beta$ in vitro causes increased expression of the ECM component, biglycan. Moreover, biglycan-deficient male mice exhibit increased $\alpha$-SMA, TFG- $\beta$, and Smad 2 expression, and the cardiac fibroblasts differentiate to myofibroblasts. The abundance of the activated myofibroblasts leads to increased ventricular stiffness and adverse remodeling. Hence, the biglycan could be a potential target in the battle against the unwanted remodeling of heart tissue (Melchior-Becker et al., 2011). Lastly, the endogenous hormone relaxin has been proven to suppress the signaling of TFG- $\beta 1$, halt the differentiation of fibroblast to myofibroblast, and consequently interrupt fibrosis and cardiac tissue remodeling (Samuel et al., 2011). Administration of relaxin to rat cardiac fibroblasts inhibits their response to Ang-II and leads to reduced collagen expression and $\alpha$-SMA expression. The interruption of fibrosis in sites remote from the infarct area would be beneficial in preventing myocardial stiffening. Relaxin was also found to stimulate gelatinases (or MMPs), hence contributing to the degradation of collagen and the attenuated fibrosis. The interesting fact is that these MMPs convert ET-1 into its active molecule ET- $1_{1-32}$ (Grossman \& Frishman, 2010), which is an agonist for $\mathrm{ET}_{\mathrm{B}}$ receptors, and their activation leads to myofibroblast differentiation and increased collagen deposition. Therefore, more research is needed to ascertain what the net effect of relaxin on fibrosis and cardiac remodeling is.

\section{SUMMARY}

Cardiac tissue is a dynamic environment in which cellular and noncellular factors interact with each other under normal conditions or in pathologic states, such as following MI. The interest for myofibroblasts has been constantly growing because they are the cells producing collagen and they lead to the healing of the wounded heart tissue after an infarct. However, fibrosis might extend to noninfarcted sites that are remote from the infarct area and cause adverse remodeling of the cardiac tissue. This eventually leads to the development of congestive heart failure, which can be lethal. Still, the exact underlying factors affecting myofibroblasts during wound healing post-MI are far from being completely understood; hence, more research is needed in this field. In Table 1, we have listed the challenges that will 
Table 1. Future Challenges in the Targeting of Myofibroblasts during the Cardiac Wound Healing.

Myofibroblast imaging and therapy post-MI

Underlying mechanisms of myofibroblast loss in dilatational CHF Clinical use of miRNAs to ascertain side-effects profile

Synergistic effect of ACEI, AT1-receptor antagonists, and novel compounds (e.g., involvement of Wnt/Fzd-pathway)

Further investigation of electrophysiological and mechanical stimuli

Holistic investigation of various signaling pathways and the way in which they cross-talk

have to be faced to bring myofibroblast-directed pharmacotherapy to the next level. The currently available pharmacotherapeutic arsenal is far from being regarded as complete. It reduces mortality and morbidity, but it has not been successful in causing regression in already fibrotic and hypertrophic cardiac tissues. Several promising therapeutic tools-targeting the myofibroblast itself-have been developed and have shown encouraging results in the lab, but their clinical value is yet to be evaluated. The ideal drug therapy would offer an optimized wound healing with a compact and minimized scar, while on the same time avoiding the fibrosis remote from the infarct area and the ventricular dilatation. An approach like this would be beneficial for the entire heart and should be the challenge for the near future.

\section{ACKNOWLEDGMENTS}

The financial support for this research line by the Department of Economic Affairs of The Netherlands (BSIK grant 03033) is gratefully acknowledged.

\section{RefERENCES}

Aisagbonhi, O., Rai, M., Ryzhov, S., Atria, N., Feoktistov, I. \& Hatzopoulos, A.K. (2011). Experimental myocardial infarction triggers canonical Wnt signaling and endothelial-tomesenchymal transition. Dis Model Mech 4(4), 469-483.

Akasaka, T. (2010). What can we expect in PCI in patients with chronic coronary artery disease. Indication of PCI for angiographically significant coronary artery stenosis without objective evidence of myocardial ischemia (Con). Circ J 75(1), 211217; discussion 210.

Akiyoshi, S., Inoue, H., Hanai, J., Kusanagi, K., Nemoto, N., Miyazono, K. \& Kawabata, M. (1999). c-Ski acts as a transcriptional co-repressor in transforming growth factor-beta signaling through interaction with smads. J Biol Chem 274(49), 35269-35277.

Banerjee, I., Fuseler, J.W., Intwala, A.R. \& Baudino, T.A. (2009). IL-6 loss causes ventricular dysfunction, fibrosis, reduced capillary density, and dramatically alters the cell populations of the developing and adult heart. Am J Physiol Heart Circ Physiol 296(5), H1694-H1704.

Baudino, T.A., Carver, W., Giles, W. \& Borg, T.K. (2006). Cardiac fibroblasts: Friend or foe? Am J Physiol Heart Circ Physiol 291(3), H1015-H1026.
BAUM, J. \& Duffy, H.S. (2011). Fibroblasts and myofibroblasts: What are we talking about? J Cardiovasc Pharmacol 57 (4), 376-379.

Bellini, A. \& Mattoli, S. (2007). The role of the fibrocyte, a bone marrow-derived mesenchymal progenitor, in reactive and reparative fibroses. Lab Invest 87 (9), 858-870.

Beltrami, C.A., Finato, N., Rocco, M., Feruglio, G.A., PuriCelli, C., Cigola, E., Quaini, F., Sonnenblick, E.H., Olivetti, G. \& Anversa, P. (1994). Structural basis of end-stage failure in ischemic cardiomyopathy in humans. Circulation 89(1), 151-163.

Blankesteijn, W.M., Essers-Janssen, Y.P., Verluyten, M.J., DaeMEN, M.J. \& Smits, J.F. (1997). A homologue of Drosophila tissue polarity gene frizzled is expressed in migrating myofibroblasts in the infarcted rat heart. Nat Med 3(5), 541-544.

Blankesteijn, W.M., van de Schans, V.A., ter Horst, P. \& Smits, J.F. (2008). The Wnt/frizzled/GSK-3 beta pathway: A novel therapeutic target for cardiac hypertrophy. Trends Pharmacol Sci 29(4), 175-180.

Brilla, C.G., Maisch, B., Zhou, G. \& Weber, K.T. (1995). Hormonal regulation of cardiac fibroblast function. Eur Heart $J$ 16(Suppl C), 45-50.

Brilla, C.G., Zhou, G., Matsubara, L. \& Weber, K.T. (1994). Collagen metabolism in cultured adult rat cardiac fibroblasts: Response to angiotensin II and aldosterone. J Mol Cell Cardiol 26(7), 809-820.

Bui, A.L., Horwich, T.B. \& Fonarow, G.C. (2011). Epidemiology and risk profile of heart failure. Nat Rev Cardiol 8(1), 30-41.

BujA, L.M. \& VelA, D. (2008). Cardiomyocyte death and renewal in the normal and diseased heart. Cardiovasc Pathol 17(6), 349-374.

Bujak, M. \& Frangogiannis, N.G. (2007). The role of TGF-beta signaling in myocardial infarction and cardiac remodeling. Cardiovasc Res 74(2), 184-195.

Bujak, M., Ren, G., Kweon, H.J., Dobaczewski, M., Reddy, A., Taffet, G., Wang, X.F. \& Frangogiannis, N.G. (2007). Essential role of Smad3 in infarct healing and in the pathogenesis of cardiac remodeling. Circulation 116(19), 2127-2138.

Camelliti, P., Borg, T.K. \& Kohl, P. (2005). Structural and functional characterisation of cardiac fibroblasts. Cardiovasc Res 65(1), 40-51.

Campbell, J. \& Hilleman, D. (2010). Recombinant peptides in thrombolysis. Semin Thromb Hemost 36 (5), 529-536.

Carthy, J.M., Garmaroudi, F.S., Luo, Z. \& McManus, B.M. (2011). Wnt3a induces myofibroblast differentiation by upregulating TGF-beta signaling through SMAD2 in a beta-catenindependent manner. PLoS One 6(5), e19809.

Cave, A.C., Brewer, A.C., Narayanapanicker, A., Ray, R., Grieve, D.J., WAlker, S. \& Shah, A.M. (2006). NADPH oxidases in cardiovascular health and disease. Antioxid Redox Signal 8(5-6), 691-728.

Cleutjens, J.P., Blankesteijn, W.M., Daemen, M.J. \& Smits, J.F. (1999). The infarcted myocardium: Simply dead tissue, or a lively target for therapeutic interventions. Cardiovasc Res 44(2), 232-241.

Cleutjens, J.P., Verluyten, M.J., Smiths, J.F. \& Daemen, M.J. (1995). Collagen remodeling after myocardial infarction in the rat heart. Am J Pathol 147(2), 325-338.

Cortez, D.M., Feldman, M.D., Mummidi, S., Valente, A.J., Steffensen, B., Vincenti, M., Barnes, J.L. \& Chandrasekar, B. (2007). IL-17 stimulates MMP-1 expression in primary human cardiac fibroblasts via p38 MAPK- and ERK1/2-dependent C/EBP-beta, NF-kappaB, and AP-1 activation. Am J Physiol Heart Circ Physiol 293(6), H3356-H3365. 
Cucoranu, I., Clempus, R., Dikalova, A., Phelan, P.J., Ariyan, S., Dikalov, S. \& Sorescu, D. (2005). NAD(P)H oxidase 4 mediates transforming growth factor-beta1-induced differentiation of cardiac fibroblasts into myofibroblasts. Circ Res 97(9), 900-907.

Cunnington, R.H., Wang, B., Ghavami, S., Bathe, K.L., RatTAN, S.G. \& Dixon, I.M. (2011). Antifibrotic properties of c-Ski and its regulation of cardiac myofibroblast phenotype and contractility. Am J Physiol Cell Physiol 300(1), C176-C186.

Dewald, O., Ren, G., Duerr, G.D., Zoerlein, M., Klemm, C., Gersch, C., Tincey, S., Michael, L.H., Entman, M.L. \& Frangogiannis, N.G. (2004). Of mice and dogs: Speciesspecific differences in the inflammatory response following myocardial infarction. Am J Pathol 164(2), 665-677.

Diaz-Flores, L., Gutierrez, R., Madrid, J.F., Varela, H., Valladares, F., Acosta, E., Martin-Vasallo, P. \& Diaz-Flores, L., JR. (2009). Pericytes. Morphofunction, interactions and pathology in a quiescent and activated mesenchymal cell niche. Histol Histopathol 24(7), 909-969.

Dickson, M.C., Martin, J.S., Cousins, F.M., Kulkarni, A.B., Karlsson, S. \& Akhurst, R.J. (1995). Defective haematopoiesis and vasculogenesis in transforming growth factor-beta 1 knock out mice. Development 121(6), 1845-1854.

Dixon, I.M. (2010). The soluble interleukin 6 receptor takes its place in the pantheon of interleukin 6 signaling proteins: Phenoconversion of cardiac fibroblasts to myofibroblasts. $H y$ pertension 56(2), 193-195.

Dobaczewski, M., Bujak, M., Li, N., Gonzalez-Quesada, C., Mendoza, L.H., Wang, X.F. \& Frangogiannis, N.G. (2010). Smad3 signaling critically regulates fibroblast phenotype and function in healing myocardial infarction. Circ Res 107(3), $418-428$.

Dobaczewski, M., Bujak, M., Zymek, P., Ren, G., Entman, M.L. \& Frangogiannis, N.G. (2006). Extracellular matrix remodeling in canine and mouse myocardial infarcts. Cell Tissue Res 324(3), 475-488.

Dobaczewski, M., Chen, W. \& Frangogiannis, N.G. (2011). Transforming growth factor (TGF)-beta signaling in cardiac remodeling. J Mol Cell Cardiol 51(4), 600-606.

Duisters, R.F., Tijsen, A.J., Schroen, B., Leenders, J.J., Lentink, V., van der Made, I., Herias, V., van Leeuwen, R.E., Schellings, M.W., Barenbrug, P., Maessen, J.G., Heymans, S., Pinto, Y.M. \& Creemers, E.E. (2009). miR-133 and miR-30 regulate connective tissue growth factor: Implications for a role of microRNAs in myocardial matrix remodeling. Circ Res 104(2), 170-178, 176p following 178.

Ellmers, L.J., Scott, N.J., Medicherla, S., Pilbrow, A.P., Bridgman, P.G., Yandle, T.G., Richards, A.M., Protter, A.A. \& Cameron, V.A. (2008). Transforming growth factor-beta blockade down-regulates the renin-angiotensin system and modifies cardiac remodeling after myocardial infarction. Endocrinology 149(11), 5828-5834.

Fix, C., Bingham, K. \& CARver, W. (2011). Effects of interleukin-18 on cardiac fibroblast function and gene expression. Cytokine 53(1), 19-28.

Fomovsky, G.M. \& Holmes, J.W. (2010). Evolution of scar structure, mechanics, and ventricular function after myocardial infarction in the rat. Am J Physiol Heart Circ Physiol 298(1), H221-H228.

Fomovsky, G.M., Thomopoulos, S. \& Holmes, J.W. (2010). Contribution of extracellular matrix to the mechanical properties of the heart. J Mol Cell Cardiol 48(3), 490-496.
Frangogiannis, N.G. (2006). Targeting the inflammatory response in healing myocardial infarcts. Curr Med Chem 13(16), 1877-1893.

Frantz, S., Bauersachs, J. \& Ertl, G. (2009). Post-infarct remodelling: Contribution of wound healing and inflammation. Cardiovasc Res 81(3), 474-481.

Frantz, S., Hu, K., Adamek, A., Wolf, J., Sallam, A., Maier, S.K., Lonning, S., Ling, H., Ertl, G. \& Bauersachs, J. (2008). Transforming growth factor beta inhibition increases mortality and left ventricular dilatation after myocardial infarction. Basic Res Cardiol 103(5), 485-492.

Freed, D.H., Borowiec, A.M., Angelovska, T. \& Dixon, I.M. (2003). Induction of protein synthesis in cardiac fibroblasts by cardiotrophin-1: Integration of multiple signaling pathways. Cardiovasc Res 60(2), 365-375.

Freed, D.H., Cunnington, R.H., Dangerfield, A.L., Sutton, J.S. \& Dixon, I.M. (2005). Emerging evidence for the role of cardiotrophin-1 in cardiac repair in the infarcted heart. Cardiovasc Res 65(4), 782-792.

Fries, K.M., Blieden, T., Looney, R.J., Sempowski, G.D., Silvera, M.R., Willis, R.A. \& Phipps, R.P. (1994). Evidence of fibroblast heterogeneity and the role of fibroblast subpopulations in fibrosis. Clin Immunol Immunopathol 72(3), 283-292.

Gabbiani, G., Ryan, G.B. \& Majne, G. (1971). Presence of modified fibroblasts in granulation tissue and their possible role in wound contraction. Experientia 27 (5), 549-550.

Ge, Y., Bagnall, A., Stricklett, P.K., Webb, D., Kotelevtsev, Y. \& Kohan, D.E. (2008). Combined knockout of collecting duct endothelin A and B receptors causes hypertension and sodium retention. Am J Physiol Renal Physiol 295(6), F1635-F1640.

Grossman, J. \& Frishman, W.H. (2010). Relaxin: A new approach for the treatment of acute congestive heart failure. Cardiol Rev 18(6), 305-312.

Guarda, E., Katwa, L.C., Myers, P.R., Tyagi, S.C. \& Weber, K.T. (1993). Effects of endothelins on collagen turnover in cardiac fibroblasts. Cardiovasc Res 27(12), 2130-2134.

Gurantz, D., Cowling, R.T., Varki, N., Frikovsky, E., Moore, C.D. \& Greenberg, B.H. (2005). IL-1beta and TNF-alpha upregulate angiotensin II type 1 (AT1) receptors on cardiac fibroblasts and are associated with increased AT1 density in the post-MI heart. J Mol Cell Cardiol 38(3), 505-515.

He, W., Zhang, L., Ni, A., Zhang, Z., Mirotsou, M., Mao, L., Pratt, R.E. \& Dzau, V.J. (2010). Exogenously administered secreted frizzled related protein 2 (Sfrp2) reduces fibrosis and improves cardiac function in a rat model of myocardial infarction. Proc Natl Acad Sci USA 107 (49), 21110-21115.

Hecker, L., Vittal, R., Jones, T., Jagirdar, R., Luckhardt, T.R., Horowitz, J.C., Pennathur, S., Martinez, F.J. \& Thannickal, V.J. (2009). NADPH oxidase- 4 mediates myofibroblast activation and fibrogenic responses to lung injury. Nat Med 15(9), 1077-1081.

Hinz, B. (2007). Formation and function of the myofibroblast during tissue repair. J Invest Dermatol 127 (3), 526-537.

Hinz, B., Celetta, G., Tomasek, J.J., Gabbiani, G. \& Chaponnier, C. (2001). Alpha-smooth muscle actin expression upregulates fibroblast contractile activity. Mol Biol Cell 12(9), 2730-2741.

Hinz, B. \& GabBiani, G. (2003). Mechanisms of force generation and transmission by myofibroblasts. Curr Opin Biotechnol 14(5), 538-546.

Holmes, J.W., Borg, T.K. \& Covell, J.W. (2005). Structure and mechanics of healing myocardial infarcts. Annu Rev Biomed Eng 7, 223-253. 
Holmes, J.W., Nunez, J.A. \& Covell, J.W. (1997). Functional implications of myocardial scar structure. Am J Physiol 272(5 Pt 2), H2123-H2130.

Husse, B., Briest, W., Homagk, L., Isenberg, G. \& Gekle, M. (2007). Cyclical mechanical stretch modulates expression of collagen I and collagen III by PKC and tyrosine kinase in cardiac fibroblasts. Am J Physiol Regul Integr Comp Physiol 293(5), R1898-R1907.

Hyde, A., Blondel, B., Matter, A., Cheneval, J.P., Filloux, B. \& Girardier, L. (1969). Homo- and heterocellular junctions in cell cultures: An electrophysiological and morphological study. Prog Brain Res 31, 283-311.

KatwA, L.C. (2003). Cardiac myofibroblasts isolated from the site of myocardial infarction express endothelin de novo. Am J Physiol Heart Circ Physiol 285(3), H1132-H1139.

Katwa, L.C., Campbell, S.E., Tyagi, S.C., Lee, S.J., Cicila, G.T. \& WEBER, K.T. (1997). Cultured myofibroblasts generate angiotensin peptides de novo. J Mol Cell Cardiol 29(5), 1375-1386.

Kim, S. \& Iwao, H. (2000). Molecular and cellular mechanisms of angiotensin II-mediated cardiovascular and renal diseases. Pharmacol Rev 52(1), 11-34.

Kober, L., Torp-Pedersen, C., Carlsen, J.E., Bagger, H., Eliasen, P., Lyngborg, K., Videbaek, J., Cole, D.S., Auclert, L. \& Pauly, N.C. (1995). A clinical trial of the angiotensin-converting-enzyme inhibitor trandolapril in patients with left ventricular dysfunction after myocardial infarction. Trandolapril Cardiac Evaluation (TRACE) Study Group. N Engl J Med 333(25), 1670-1676.

Konstam, M.A., Kramer, D.G., Patel, A.R., Maron, M.S. \& Udelson, J.E. (2011). Left ventricular remodeling in heart failure: Current concepts in clinical significance and assessment. JACC Cardiovasc Imaging 4(1), 98-108.

Krishnamurthy, P., Rajasingh, J., Lambers, E., Qin, G., Losordo, D.W. \& Kishore, R. (2009). IL-10 inhibits inflammation and attenuates left ventricular remodeling after myocardial infarction via activation of STAT3 and suppression of HuR. Circ Res 104(2), e9-e18.

Laeremans, H., Hackeng, T.M., van Zandvoort, M.A., Thijssen, V.L., Janssen, B.J., Ottenheijm, H.C., Smits, J.F. \& Blankesteijn, W.M. (2011). Blocking of frizzled signaling with a homologous peptide fragment of $\mathrm{Wnt} 3 \mathrm{a} / \mathrm{Wnt} 5 \mathrm{a}$ reduces infarct expansion and prevents the development of heart failure after myocardial infarction. Circulation 124(15), 1626-1635.

Laeremans, H., Rensen, S.S., Ottenheijm, H.C., Smits, J.F. \& Blankesteijn, W.M. (2010). Wnt/frizzled signalling modulates the migration and differentiation of immortalized cardiac fibroblasts. Cardiovasc Res 87(3), 514-523.

Leask, A. \& Abraham, D.J. (2004). TGF-beta signaling and the fibrotic response. FASEB J 18(7), 816-827.

Lefkowitz, R.J., Rockman, H.A. \& КосH, W.J. (2000). Catecholamines, cardiac beta-adrenergic receptors, and heart failure. Circulation 101(14), 1634-1637.

Lenga, Y., Koh, A., Perera, A.S., McCulloch, C.A., Sodek, J. \& ZoHAR, R. (2008). Osteopontin expression is required for myofibroblast differentiation. Circ Res 102(3), 319-327.

Lijnen, P.J., Petrov, V.V. \& Fagard, R.H. (2001). Angiotensin II-induced stimulation of collagen secretion and production in cardiac fibroblasts is mediated via angiotensin II subtype 1 receptors. J Renin Angiotensin Aldosterone Syst 2(2), 117-122.

Manabe, R., Ohe, N., Maeda, T., Fukuda, T. \& Sekiguchi, K. (1997). Modulation of cell-adhesive activity of fibronectin by the alternatively spliced EDA segment. J Cell Biol 139(1), 295-307.
Matsui, Y., Morimoto, J. \& Uede, T. (2010). Role of matricellular proteins in cardiac tissue remodeling after myocardial infarction. World J Biol Chem 1(5), 69-80.

McKelvie, R.S., Yusuf, S., Pericak, D., Avezum, A., Burns, R.J., Probstfield, J., Tsuyuki, R.T., White, M., Rouleau, J., Latini, R., Maggioni, A., Young, J. \& Pogue, J. (1999). Comparison of candesartan, enalapril, and their combination in congestive heart failure: Randomized evaluation of strategies for left ventricular dysfunction (RESOLVD) pilot study. The RESOLVD Pilot Study Investigators. Circulation 100(10), 1056-1064.

McMahon, J.A. \& McMahon, A.P. (1989). Nucleotide sequence, chromosomal localization and developmental expression of the mouse int-1-related gene. Development 107(3), 643-650.

McMurray, J.J., Ostergren, J., Swedberg, K., Granger, C.B., Held, P., Michelson, E.L., Olofsson, B., Yusuf, S. \& Pfeffer, M.A. (2003). Effects of candesartan in patients with chronic heart failure and reduced left-ventricular systolic function taking angiotensin-converting-enzyme inhibitors: The CHARMAdded trial. Lancet 362 (9386), 767-771.

McMurray, J.J. \& Pfeffer, M.A. (2005). Heart failure. Lancet 365(9474), 1877-1889.

Melchior-Becker, A., Dai, G., Ding, Z., Schafer, L., Schrader, J., Young, M.F. \& Fischer, J.W. (2011). Deficiency of biglycan causes cardiac fibroblasts to differentiate into a myofibroblast phenotype. J Biol Chem 286(19), 17365-17375.

Melendez, G.C., McLarty, J.L., Levick, S.P., Du, Y., Janicki, J.S. \& Brower, G.L. (2010). Interleukin 6 mediates myocardial fibrosis, concentric hypertrophy, and diastolic dysfunction in rats. Hypertension 56(2), 225-231.

Meran, S. \& Steadman, R. (2011). Fibroblasts and myofibroblasts in renal fibrosis. Int J Exp Pathol 92(3), 158-167.

Meszaros, J.G., Gonzalez, A.M., Endo-Mochizuki, Y., Villegas, S., Villarreal, F. \& Brunton, L.L. (2000). Identification of $\mathrm{G}$ protein-coupled signaling pathways in cardiac fibroblasts: Cross talk between G(q) and G(s). Am J Physiol Cell Physiol 278(1), C154-C162.

Minnaard-Huiban, M., Hermans, J.J., Essen, H., Bitsch, N. \& Smits, J.F. (2008). Comparison of the effects of intrapericardial and intravenous aldosterone infusions on left ventricular fibrosis in rats. Eur J Heart Fail 10(12), 1166-1171.

NAG, A.C. (1980). Study of non-muscle cells of the adult mammalian heart: A fine structural analysis and distribution. Cytobios 28(109), 41-61.

Nahrendorf, M., Pittet, M.J. \& Swirski, F.K. (2010). Monocytes: Protagonists of infarct inflammation and repair after myocardial infarction. Circulation 121(22), 2437-2445.

Neumann, S., Huse, K., Semrau, R., Diegeler, A., Gebhardt, R., Buniatian, G.H. \& Scholz, G.H. (2002). Aldosterone and D-glucose stimulate the proliferation of human cardiac myofibroblasts in vitro. Hypertension 39(3), 756-760.

Nusse, R. \& Varmus, H.E. (1982). Many tumors induced by the mouse mammary tumor virus contain a provirus integrated in the same region of the host genome. Cell 31(1), 99-109.

Olivetti, G., Melissari, M., Balbi, T., Quaini, F., Sonnenblick, E.H. \& Anversa, P. (1994). Myocyte nuclear and possible cellular hyperplasia contribute to ventricular remodeling in the hypertrophic senescent heart in humans. J Am Coll Cardiol 24(1), 140-149.

Owan, T.E., Hodge, D.O., Herges, R.M., Jacobsen, S.J., Roger, V.L. \& Redfield, M.M. (2006). Trends in prevalence and outcome of heart failure with preserved ejection fraction. $N$ Engl $J$ Med 355(3), 251-259. 
Palmer, J.N., Hartogensis, W.E., Patten, M., Fortuin, F.D. \& Long, C.S. (1995). Interleukin-1 beta induces cardiac myocyte growth but inhibits cardiac fibroblast proliferation in culture. $J$ Clin Invest 95(6), 2555-2564.

Pellman, J., Lyon, R.C. \& Sheikh, F. (2010). Extracellular matrix remodeling in atrial fibrosis: Mechanisms and implications in atrial fibrillation. J Mol Cell Cardiol 48(3), 461-467.

Pfeffer, M.A., McMurray, J.J., Velazquez, E.J., Rouleau, J.L., Kober, L., Maggioni, A.P., Solomon, S.D., Swedberg, K., Van de Werf, F., White, H., Leimberger, J.D., Henis, M., Edwards, S., Zelenkofske, S., Sellers, M.A. \& Califf, R.M. (2003). Valsartan, captopril, or both in myocardial infarction complicated by heart failure, left ventricular dysfunction, or both. N Engl J Med 349(20), 1893-1906.

Pitt, B., Remme, W., Zannad, F., Neaton, J., Martinez, F., Roniker, B., Bittman, R., Hurley, S., Kleiman, J. \& Gatlin, M. (2003). Eplerenone, a selective aldosterone blocker, in patients with left ventricular dysfunction after myocardial infarction. N Engl J Med 348(14), 1309-1321.

Pitt, B., Zannad, F., Remme, W.J., Cody, R., Castaigne, A., Perez, A., Palensky, J. \& Wittes, J. (1999). The effect of spironolactone on morbidity and mortality in patients with severe heart failure. Randomized Aldactone Evaluation Study Investigators. N Engl J Med 341(10), 709-717.

Ponta, H., Sherman, L. \& Herrlich, P.A. (2003). CD44: From adhesion molecules to signalling regulators. Nat Rev Mol Cell Biol 4(1), 33-45.

Porter, K.E. \& Turner, N.A. (2009). Cardiac fibroblasts: At the heart of myocardial remodeling. Pharmacol Ther 123(2), 255-278.

Porter, K.E., Turner, N.A., O’Regan, D.J. \& Ball, S.G. (2004a). Tumor necrosis factor alpha induces human atrial myofibroblast proliferation, invasion and MMP-9 secretion: Inhibition by simvastatin. Cardiovasc Res 64(3), 507-515.

Porter, K.E., Turner, N.A., O’Regan, D.J., Balmforth, A.J. \& BALL, S.G. (2004b). Simvastatin reduces human atrial myofibroblast proliferation independently of cholesterol lowering via inhibition of RhoA. Cardiovasc Res 61(4), 745-755.

Post, S.R., Hammond, H.K. \& Insel, P.A. (1999). Beta-adrenergic receptors and receptor signaling in heart failure. Annu Rev Pharmacol Toxicol 39, 343-360.

Potts, J.D. \& Runyan, R.B. (1989). Epithelial-mesenchymal cell transformation in the embryonic heart can be mediated, in part, by transforming growth factor beta. Dev Biol 134(2), 392-401.

Prockop, D.J. \& Kivirikкo, K.I. (1995). Collagens: Molecular biology, diseases, and potentials for therapy. Annu Rev Biochem 64, 403-434.

Rehsia, N.S. \& Dhalla, N.S. (2010). Potential of endothelin-1 and vasopressin antagonists for the treatment of congestive heart failure. Heart Fail Rev 15(1), 85-101.

Ren, G., Michael, L.H., Entman, M.L. \& Frangogiannis, N.G. (2002). Morphological characteristics of the microvasculature in healing myocardial infarcts. J Histochem Cytochem 50(1), 71-79.

Rodriguez-Pascual, F., Busnadiego, O., Lagares, D. \& Lamas, S. (2011). Role of endothelin in the cardiovascular system. Pharmacol Res 63(6), 463-472.

Roger, V.L., Go, A.S., Lloyd-Jones, D.M., Adams, R.J., Berry, J.D., Brown, T.M., Carnethon, M.R., DaI, S., De Simone, G., Ford, E.S., Fox, C.S., Fullerton, H.J., Gillespie, C., Greenlund, K.J., Hailpern, S.M., Heit, J.A., Ho, P.M., Howard, V.J., Kissela, B.M., Kittner, S.J., Lackland, D.T., Lichtman, J.H., Lisabeth, L.D., Makuc, D.M., Marcus, G.M., Marelli, A.,
Matchar, D.B., McDermott, M.M., Meigs, J.B., Moy, C.S., Mozaffarian, D., Mussolino, M.E., Nichol, G., Paynter, N.P., Rosamond, W.D., Sorlie, P.D., Stafford, R.S., Turan, T.N., Turner, M.B., Wong, N.D. \& Wylie-Rosett, J. (2011). Heart disease and stroke statistics-2011 update: A report from the American Heart Association. Circulation 123(4), e18-e209.

RoHr, S. (2009). Myofibroblasts in diseased hearts: New players in cardiac arrhythmias? Heart Rhythm 6(6), 848-856.

Rosenkranz, S. (2004). TGF-beta1 and angiotensin networking in cardiac remodeling. Cardiovasc Res 63(3), 423-432.

Samuel, C.S., Cendrawan, S., Gao, X.M., Ming, Z., Zhao, C., Kiriazis, H., Xu, Q., Tregear, G.W., Bathgate, R.A. \& Du, X.J. (2011). Relaxin remodels fibrotic healing following myocardial infarction. Lab Invest 91(5), 675-690.

Schieffer, B., Wirger, A., Meybrunn, M., Seitz, S., Holtz, J., Riede, U.N. \& Drexler, H. (1994). Comparative effects of chronic angiotensin-converting enzyme inhibition and angiotensin II type 1 receptor blockade on cardiac remodeling after myocardial infarction in the rat. Circulation 89(5), 2273-2282.

Serini, G., Bochaton-Piallat, M.L., Ropraz, P., Geinoz, A., Borsi, L., Zardi, L. \& Gabbiani, G. (1998). The fibronectin domain ED-A is crucial for myofibroblastic phenotype induction by transforming growth factor-beta1. J Cell Biol 142(3), 873-881.

Shiroshita-Takeshita, A., Brundel, B.J., Burstein, B., Leung, T.K., Mitamura, H., Ogawa, S. \& Nattel, S. (2007). Effects of simvastatin on the development of the atrial fibrillation substrate in dogs with congestive heart failure. Cardiovasc Res 74(1), 75-84.

Shi-wen, X., Kennedy, L., Renzoni, E.A., Bou-Gharios, G., DU Bois, R.M., Black, C.M., Denton, C.P., Abraham, D.J. \& LEAsk, A. (2007). Endothelin is a downstream mediator of profibrotic responses to transforming growth factor beta in human lung fibroblasts. Arthritis Rheum 56(12), 4189-4194.

Siwik, D.A., Chang, D.L. \& Colucci, W.S. (2000). Interleukin1beta and tumor necrosis factor-alpha decrease collagen synthesis and increase matrix metalloproteinase activity in cardiac fibroblasts in vitro. Circ Res 86(12), 1259-1265.

SOLVD InVESTIGATORs. (1991). Effect of enalapril on survival in patients with reduced left ventricular ejection fractions and congestive heart failure. The SOLVD Investigators. $N$ Engl J Med 325(5), 293-302.

Soonpaa, M.H., Daud, A.I., Koh, G.Y., Klug, M.G., Kim, K.K., Wang, H. \& Field, L.J. (1995). Potential approaches for myocardial regeneration. Ann NY Acad Sci 752, 446-454.

Sorrell, J.M. \& CAPLAN, A.I. (2004). Fibroblast heterogeneity: More than skin deep. J Cell Sci 117(Pt 5), 667-675.

Souders, C.A., Bowers, S.L. \& Baudino, T.A. (2009). Cardiac fibroblast: The renaissance cell. Circ Res 105(12), 1164-1176.

Strieter, R.M., Keeley, E.C., Burdick, M.D. \& Mehrad, B. (2009). The role of circulating mesenchymal progenitor cells, fibrocytes, in promoting pulmonary fibrosis. Trans Am Clin Climatol Assoc 120, 49-59.

Sumimoto, H., Miyano, K. \& Takeya, R. (2005). Molecular composition and regulation of the Nox family NAD $(\mathrm{P}) \mathrm{H}$ oxidases. Biochem Biophys Res Commun 338(1), 677-686.

Sun, Y. \& Weber, K.T. (1996). Angiotensin converting enzyme and myofibroblasts during tissue repair in the rat heart. J Mol Cell Cardiol 28(5), 851-858.

Sun, Y., Zhang, J.Q., Zhang, J. \& Ramires, F.J. (1998). Angiotensin II, transforming growth factor-betal and repair in the infarcted heart. J Mol Cell Cardiol 30(8), 1559-1569. 
Tan, S.M., Zhang, Y., Connelly, K.A., Gilbert, R.E. \& Kelly, D.J. (2010). Targeted inhibition of activin receptor-like kinase 5 signaling attenuates cardiac dysfunction following myocardial infarction. Am J Physiol Heart Circ Physiol 298(5), H1415-H1425.

Taylor, K., Patten, R.D., Smith, J.J., Aronovitz, M.J., Wight, J., Salomon, R.N. \& Konstam, M.A. (1998). Divergent effects of angiotensin-converting enzyme inhibition and angiotensin IIreceptor antagonism on myocardial cellular proliferation and collagen deposition after myocardial infarction in rats. J Cardiovasc Pharmacol 31(5), 654-660.

Thum, T., Gross, C., Fiedler, J., Fischer, T., Kissler, S., Bussen, M., Galuppo, P., Just, S., Rottbauer, W., Frantz, S., Castoldi, M., Soutschek, J., Koteliansky, V., Rosenwald, A., Basson, M.A., Licht, J.D., Pena, J.T., Rouhanifard, S.H., Muckenthaler, M.U., Tuschl, T., Martin, G.R., BauerSACHS, J. \& Engelhardt, S. (2008). MicroRNA-21 contributes to myocardial disease by stimulating MAP kinase signalling in fibroblasts. Nature 456(7224), 980-984.

Tomasek, J.J., Gabbiani, G., Hinz, B., Chaponnier, C. \& Brown, R.A. (2002). Myofibroblasts and mechano-regulation of connective tissue remodelling. Nat Rev Mol Cell Biol 3(5), 349-363.

Trueblood, N.A., Xie, Z., Communal, C., Sam, F., Ngoy, S., Liaw, L., Jenkins, A.W., Wang, J., Sawyer, D.B., Bing, O.H., Apstein, C.S., Colucci, W.S. \& Singh, K. (2001). Exaggerated left ventricular dilation and reduced collagen deposition after myocardial infarction in mice lacking osteopontin. Circ Res 88(10), 1080-1087.

Turner, N.A., Das, A., Warburton, P., O’Regan, D.J., Ball, S.G. \& Porter, K.E. (2009). Interleukin-1alpha stimulates proinflammatory cytokine expression in human cardiac myofibroblasts. Am J Physiol Heart Circ Physiol 297(3), H1117-H1127.

Turner, N.A., Porter, K.E., Smith, W.H., White, H.L., Ball, S.G. \& Balmforth, A.J. (2003). Chronic beta2-adrenergic receptor stimulation increases proliferation of human cardiac fibroblasts via an autocrine mechanism. Cardiovasc Res 57 (3), 784-792.

Turner, N.A., Warburton, P., O’Regan, D.J., Ball, S.G. \& PorTER, K.E. (2010). Modulatory effect of interleukin-1alpha on expression of structural matrix proteins, MMPs and TIMPs in human cardiac myofibroblasts: Role of p38 MAP kinase. $\mathrm{Ma}$ trix Biol 29(7), 613-620.

van den Borne, S.W., Cleutjens, J.P., Hanemaajer, R., Creemers, E.E., Smits, J.F., Daemen, M.J. \& Blankesteijn, W.M. (2009a). Increased matrix metalloproteinase- 8 and -9 activity in patients with infarct rupture after myocardial infarction. Cardiovasc Pathol 18(1), 37-43.

van den Borne, S.W., Diez, J., Blankesteijn, W.M., Verjans, J., Hofstra, L. \& Narula, J. (2010). Myocardial remodeling after infarction: The role of myofibroblasts. Nat Rev Cardiol 7(1), 30-37.

van den Borne, S.W., Isobe, S., Verjans, J.W., Petrov, A., Lovhaug, D., Li, P., Zandbergen, H.R., Ni, Y., Frederik, P., Zhou, J., Arbo, B., Rogstad, A., Cuthbertson, A., Chettibi, S., Reutelingsperger, C., Blankesteijn, W.M., Smits, J.F., Daemen, M.J., Zannad, F., Vannan, M.A., Narula, N., Pitt, B., Hofstra, L. \& Narula, J. (2008). Molecular imaging of interstitial alterations in remodeling myocardium after myocardial infarction. J Am Coll Cardiol 52(24), 2017-2028.

van den Borne, S.W., van de Schans, V.A., Strzelecka, A.E., Vervoort-Peters, H.T., Lijnen, P.M., Cleutjens, J.P., Smits, J.F., Daemen, M.J., Janssen, B.J. \& Blankesteijn, W.M. (2009b). Mouse strain determines the outcome of wound healing after myocardial infarction. Cardiovasc Res 84(2), 273-282. van der LaAn, A.M., Piek, J.J. \& van Royen, N. (2009). Targeting angiogenesis to restore the microcirculation after reperfused MI. Nat Rev Cardiol 6(8), 515-523.

van de Schans, V.A., Smits, J.F. \& Blankesteijn, W.M. (2008). The Wnt/frizzled pathway in cardiovascular development and disease: Friend or foe? Eur J Pharmacol 585(2-3), 338-345.

van Rooij, E., Sutherland, L.B., Thatcher, J.E., DiMaio, J.M., Naseem, R.H., Marshall, W.S., Hill, J.A. \& Olson, E.N. (2008). Dysregulation of microRNAs after myocardial infarction reveals a role of miR-29 in cardiac fibrosis. Proc Natl Acad Sci USA 105(35), 13027-13032.

Wang, J., Zohar, R. \& McCulloch, C.A. (2006). Multiple roles of alpha-smooth muscle actin in mechanotransduction. Exp Cell Res 312(3), 205-214.

Webber, J., Jenkins, R.H., Meran, S., Phillips, A. \& Steadman, R. (2009). Modulation of TGFbeta1-dependent myofibroblast differentiation by hyaluronan. Am J Pathol 175(1), 148-160.

Wexler, D.J., Chen, J., Smith, G.L., Radford, M.J., YaAri, S., Bradford, W.D. \& Krumholz, H.M. (2001). Predictors of costs of caring for elderly patients discharged with heart failure. Am Heart J 142 (2), 350-357.

WHO. (2011). WHO Fact Sheet $\mathrm{N}^{\circ} 317$-Cardiovascular diseases (CVDs). Available at www.who.int/mediacentre/factsheets/fs317/ en/24-05-11.

Widyantoro, B., Emoto, N., Nakayama, K., Anggrahini, D.W., Adiarto, S., Iwasa, N., Yagi, K., Miyagawa, K., Rikitake, Y., Suzuki, T., Kisanuki, Y.Y., Yanagisawa, M. \& Hirata, K. (2010). Endothelial cell-derived endothelin-1 promotes cardiac fibrosis in diabetic hearts through stimulation of endothelialto-mesenchymal transition. Circulation 121(22), 2407-2418.

Willems, I.E., Havenith, M.G., De Mey, J.G. \& Daemen, M.J. (1994). The alpha-smooth muscle actin-positive cells in healing human myocardial scars. Am J Pathol 145(4), 868-875.

Yu, C.M., Tipoe, G.L., Wing-Hon Lai, K. \& LaU, C.P. (2001). Effects of combination of angiotensin-converting enzyme inhibitor and angiotensin receptor antagonist on inflammatory cellular infiltration and myocardial interstitial fibrosis after acute myocardial infarction. J Am Coll Cardiol 38(4), 12071215.

ZAK, R. (1974). Development and proliferative capacity of cardiac muscle cells. Circ Res 35(2), Suppl II:17-26.

Zeisberg, E.M., Tarnavski, O., Zeisberg, M., Dorfman, A.L., McMullen, J.R., Gustafsson, E., Chandraker, A., Yuan, X., Pu, W.T., Roberts, A.B., Neilson, E.G., SAyegh, M.H., Izumo, S. \& Kalluri, R. (2007). Endothelial-to-mesenchymal transition contributes to cardiac fibrosis. Nat Med 13(8), 952-961.

Zhang, C. (2008). MicroRNomics: A newly emerging approach for disease biology. Physiol Genomics 33(2), 139-147.

Zhang, Y., Kanter, E.M., Laing, J.G., Aprhys, C., Johns, D.C., Kardami, E. \& Yamada, K.A. (2008). Connexin43 expression levels influence intercellular coupling and cell proliferation of native murine cardiac fibroblasts. Cell Commun Adhes 15(3), 289-303.

Zhou, G., Kandala, J.C., Tyagi, S.C., Katwa, L.C. \& Weber, K.T. (1996). Effects of angiotensin II and aldosterone on collagen gene expression and protein turnover in cardiac fibroblasts. Mol Cell Biochem 154(2), 171-178.

Zymek, P., Nah, D.Y., Bujak, M., Ren, G., Koerting, A., Leucker, T., Huebener, P., Taffet, G., Entman, M. \& Frangogiannis, N.G. (2007). Interleukin-10 is not a critical regulator of infarct healing and left ventricular remodeling. Cardiovasc Res 74(2), 313-322. 